Internal Medicine | Review article

\section{Ozone Preconditioning: Waking up the dragon}

\section{K. E. Thorp ${ }^{1}$, James A. Thorp ${ }^{2 \star}$}

${ }^{1} \mathrm{MD}$, Department of Radiology, Sparrow Health System, 1215 E. Michigan Avenue, Lansing, Ml 48909. k.t@earthlink.net

${ }^{2} \mathrm{MD}$, Department of Obstetrics \& Gynecology, Division of Maternal Fetal Medicine, Sisters of St. Mary's Health System, St. Louis, Missouri. jathorp@bellsouth.net

\author{
Submitted: 14 May 2021 \\ Approved: 23 May 2021 \\ Published: 24 May 2021
}

Address for correspondence:

James A. Thorp, MD, Department of Obstetrics \&

Gynecology, Division of Maternal Fetal Medicine, Sisters of St. Mary's Health System, St. Louis, Missouri.

E-mail: jathorp@bellsouth.net

How to cite this article: Thorp KE, Thorp JA. Ozone Preconditioning: Waking up the dragon. G Med Sci. 2021; 2(3): 010-039.

https://www.doi.org/10.46766/thegms.intmed.21051402

Copyright: (c) 2021 K. E. Thorp, James A. Thorp. This is an Open Access article distributed under the Creative Commons Attribution License, which permits unrestricted use, distribution, and reproduction in any medium, provided the original work is properly cited.

It is said that no discovery is complete until its implications have been fully realized. The identification of a previously unrecognized phenomenon says little of its potential effects. What appears as a stroke of good luck can culminate in disaster; misfortune may harbor unimagined potential. Discovery is a double-edged sword that manifests only over time. Nowhere is this aphorism more applicable than in contemporary medical science.

The tried-and-true mode of discovery in $20^{\text {th }}$ century medical therapeutics falls along this line: the beneficial effect of a substance is observed empirically during random testing or, conversely, new compounds are synthesized based on some existing pharmacologic principle; the substance undergoes testing in animals and, if no undesirable consequences ensue, clinical studies in humans are conducted. Ultimately, if the substance passes muster on these counts, it will be approved by some regulatory agency, the FDA for example, for general use in individuals with appropriate medical indications.

In the case of the numerous drug-induced mass tragedies that punctuated $20^{\text {th }}$ century medicine-sulfanilamide, thalidomide, isoproterenol, diethystilbesterol, fenoterol, Fenfluramine-phentermine, cerivastatin, or rofecoxibthe disaster can generally be attributed to insufficient vetting of a substance, malfeasance by the pharmaceutical concern, failure of proper oversight by regulatory agencies or any combination of the three. In such cases completion of the discovery process then occurs at the expense of the public after the substance is in general circulation.
Undoubtedly the most conspicuous exception to this rule of thumb is found in the strange case of ozone, a volatile atmospheric gas, in which every aspect of medical convention and discovery is turned topsy-turvy. From the beginning ozone was labelled as a toxic environmental substance, a conclusion borne out by numerous laboratory and epidemiologic studies. When in excess in atmospheric air ozone produces difficulty in breathing, cough, nasal congestion, tear formation, chest discomfort and, in susceptible individuals, predisposes to asthma attacks, angina pectoris and occasional heart attack. Such effects incriminate ozone as a hazard to human health.

Laboratory studies confirm such effects at the cellular and molecular level. A powerful oxidant, ozone diverts energy intended for cellular use resulting in impaired mitochondrial function, diminished ATP synthesis, production of reactive oxygen species and a host of toxic intermediary compounds. Its mechanism of action has been documented in so many studies in animals and humans over the past century as to galvanize consensus among those familiar with the topic. It is hardly surprising that regulatory agencies seek to restrict atmospheric levels and limit human exposure to its deleterious influences. But as in so many other cases things aren't quite as simple as they first appear.

In the 1970s reports began to surface of paradoxical benefits from small ozone doses administered by various routes that bypass the lungs and, instead, funnel directly into the blood. In the 1980 s physicians reported beneficial results with ozone in HIV patients. Later studies indicated 
that ozone enhances immune function. The list of disorders that responded favourably to ozone treatment grew dramatically: autoimmune conditions, peripheral vascular disease, fibromyalgia, neurodegenerative diseases, renal and gastrointestinal disorders, various cancers, healing of wounds and more. Recent studies found beneficial effects in Covid-19 pneumonitis.

What is at play in this dramatic and unexpected turn of events? Why has there been such pushback from regulatory agencies like the FDA? And why has organized medicine been so slow to recognize the vast potential of ozone and implement it into its therapeutic regimen? Based on accrued data, this lapse too appears to be playing out at the expense of the public. In this paper we examine the science behind the ozone phenomenon. Emerging recognition of its vast therapeutic potential has been greatly amplified by two seemingly unrelated discoveries in the closing decades of the $20^{\text {th }}$ century.

The first was the discovery of the preconditioning (PC) phenomenon by Murry et al in 1986 which found that one or more applications of 'sublethal' amounts of physiologic stressors like ischemia, hyperthermia, or toxins induce a powerful counter-response that confers body-wide protection to subsequent insults acutely and for up to $72 \mathrm{~h}$ afterward. The PC phenomenon is now recognized to be the most powerful form of endogenous protection ever discovered. The second linchpin discovery was the recognition of an organized energy field in the blood that originates through the contraction and dilation of the heart. As we will see ozone activates this energy field and asserts its effects via the PC phenomenon.

\section{The Ozone Paradox}

In the 1880s, German pharmacologist Hugo Schulz examined the effects of toxic substances on yeast cultures. Using a variety of compounds over a broad range of concentrations, and expecting to find progressive dose-dependent toxicity, Schulz was taken aback to observe that while all agents produced toxic effects at high doses, they paradoxically stimulated fermentation in yeast cultures at low concentrations [1]. Schulz found similar reports in the research literature.

Upon sharing his findings with homeopathic physician Rudolph Arndt, they deduced that such results must be independent of the particular chemical applied and, instead, represent an adaptive response on the part of the organism. Administered toxic substances have more than one effect and act in a biphasic manner: small doses stimulate; large doses inhibit. This axiom came to be known as the Arndt-Schulz Rule.

In the 1930s the Arndt-Schulz Rule came under blistering attack by English pharmacologists and by decade's end had apparently been discredited [2, 3]. Nonetheless a steady stream of reports continued to surface in the scientific literature describing biphasic effects in plants, microorganisms, insects, as well as higher organisms. In the 1940s two investigators described the effect in fungal cultures and renamed it hormesis. Reports continued to indicate that substances possessed both stimulatory and inhibitory effects [4].

In recent decades the dose-response revolution has gathered steam in large part due to the writings of toxicologist Edward Calabrese. Beginning around 2000, he published a series of illuminating papers on hormesis, which document the rise, fall and eventual revival of an excluded perspective. He cites many scientific articles confirming biphasic dose effects as well as offering deep, informed analysis of the historical currents which have shaped its complicated legacy [5-10]. Such paradoxical biphasic effects are seen with ozone.

Rats exposed to higher doses and/or longer periods of ozone developed brain dysfunction manifesting in cognitive and motor impairment. Other reports found that ozone inhalation induced pathological neuronal alterations in the brainstem, basal ganglier and hippocampal regions which would seem to explain the various functional impairments [11-14]. It is wellestablished that elevated ozone levels in inspired air are associated with increased incidence of ischemic stroke in humans [15-18].

On the other hand, an increasing number of studies support the beneficial role of ozone in the treatment of various neurological conditions. Ozone has been used for decades in acute and chronic neuropathic pain syndromes with reduction in subjective pain scores as well as analgesic requirements [19-28]. Sporadic reports suggest its potential to reduce the size of the ischemic penumbra in acute stroke and thus limit the severity of long-term functional deficits [29-32].

Recent studies point to its clinical utility in neuroinflammatory conditions like multiple sclerosis. In addition to symptomatic improvement effects include reduction of oxidation markers, proinflammatory $\mathrm{T}$-cells and cytokines and increased anti-oxidant levels, regulatory $\mathrm{T}$-cells and anti-inflammatory cytokines [33-38]. While ozone's mechanism of action has been elucidated in great detail the means by which its benefits are conferred remain sketchy. And this is where the PC phenomenon comes into play.

Murry and colleagues executed their original PC experiment in an attempt to determine mechanisms at play in myocardial infarct. They had deduced that infarct must be secondary to either exhaustion of energy reserves or build-up of toxic metabolites. They tested 
whether intermittently reopening the coronary arteries to allow for brief return of blood flow altered the course of cellular injury [39]. In a control group of dogs a coronary artery was clamped for 40 minutes to assess the extent of infarct damage. Another group underwent a series of four 5-minute arterial occlusions interrupted by 5-minute intervals of reperfusion. Afterward the artery was clamped for 40 minutes. To their complete surprise, animals that received PC pulses had only about $25 \%$ of damage as the control group. How can this be?

The protection afforded by the PC phenomenon has been substantiated in many human and animal studies. When the PC sequence is applied prior to a prolonged ischemic episode a period of protection ensues that lasts about $2-3$ h during which ischemia-mediated damage is markedly reduced. Biochemical analysis suggests that PC supposedly slows the rate of ATP consumption, anaerobic glycolysis, lactate accumulation, and development of tissue acidosis. Surprisingly, cardiovascular functions like endothelial dependent vasodilation are preserved and the myocardium becomes resistant to potentially lethal arrhythmias. Researchers are at a loss to explain the various effects but suggest that PC pulses somehow slow the metabolism and diminish energy demand [40-49].

A 1993 study found that preconditioning pulses applied to one vascular territory of the heart protected the rest of the heart from prolonged arterial occlusion [50]. Several years later another study found reduction in myocardial infarct size in rabbits after administration of PC pulses to skeletal muscle [51]. Reports soon followed describing protection in organs besides the heart after PC pulses in distant vascular territories. Remote PC effects involving brain, liver, intestines, kidneys, stomach and lungs were described [52-65].

The PC response originates in the cardiovascular system and blood and spreads throughout the body. PC pulses applied to any vascular bed confer systemic resistance to prolonged ischemia. RemotePCinducedbyserial inflationdeflation of a blood pressure cuff in the extremities is now used prior to various surgical procedures to limit operative and postoperative injury [66]. Reports suggest beneficial effects are transferable from one animal to another by transfusion of blood or bodily fluids [67-69]. It became recognized that the $\mathrm{PC}$ response could be induced by different means other than ischemia: hyperthermia, exercise, cardiac pacing, ethanol, volatile anesthetics, and a host of others including ozone [70-88].

A 1996 study ascribing a complex temporal signature to the PC phenomenon complicated the picture even further [89]. The initial period of heightened resistance to ischemic injury disappears after about 2-3h but then protective effects recur in echo-like fashion about $24 \mathrm{~h}$ later and persist for up to 48-72h; this is called the second window of protection. Researchers remain baffled as to its basis [90, 91]. As effects are associated with appearance of different mediator substances in the blood it appears to involve gene transcription.

Two reports in 2004 suggested that PC pulses administered after a period of prolonged ischemia, i.e., postconditioning, delivers cardioprotective effects. Postconditioning sequences can be applied either locally or at a distance with protective benefit $[92,93]$. Another study in 2011 found that remote PC delivered during an ischemic episode conferred neuroprotection [94]. Thus, whether the conditioning sequence is delivered before, during, or after a sublethal injury beneficial effects are potentially conferred [95]. Such events can only be explained on the basis of an infusion of energy reserves into the blood.

PC is now regarded as the most powerful form of body-wide protection. It has been 35 years since its discovery and 10,000's of reports in the literature have detailed its various aspects. Molecular biologists have identified dozens of potential chemical mediators and various mechanisms - heat shock proteins, adenosine, various neurotransmitters, erythropoietin, nitric oxide, oxygen-derived free radicals, ATP-sensitive potassium channels to name a few-but to date no convincing molecular explanation for the PC phenomenon has come to light [96-106].

Calabrese argues that the PC phenomenon and hormesis are one and the same but evidence does not support his claim [107, 108]. That all pharmacologically active substances operate in hormetic fashion does not imply that all agents possess the ability induce PC. Most substances exhibit a characteristic spectrum of dose-dependent side effects and appear to operate in a mechanism quite distinct from PC. What Calabrese and molecular biologists overlook is the energy equation. All molecular substances effect their change within a pre-existing energetic milieu and this is where the next discovery plays a decisive role.

Around the time Murry and colleagues stumbled upon the PC phenomenon the cardiology world was in the midst of a profound paradigm shift. For most of the $20^{\text {th }}$ century the heart had been conceived as a mechanical pump which propelled blood forward through the arteries during the systolic phase of its cycle. Diastole, in turn, was regarded as a period of passive relaxation. In the early 1980 s reports surfaced describing negative intraventricular pressures in early diastole which researchers soon realized must account for diastolic filling and the forward movement of blood $[109,110]$.

A 1986 article in Scientific American entitled The Heart as a Suction Pump advanced a new model of cardiac function [111]. A spate of articles followed in support of active dilation and by the late 1980s researchers had coined the term 'diastolic dysfunction' to designate a growing number of disease conditions associated with impaired 
outward movement of the ventricle $[113,114]$. In the mid1990s a paper refuted the propulsion theory of heart function [114]. By the 1990s imaging studies described spiral arterial flow currents which can only be explained on the basis of a suction force [115-119].

This concept explains the complex mechanics of the fetal heart: systolic forward force alone is insufficient to convey blood through the fetal circulation, extracorporeally through umbilical cord arteries, placenta, and then back into the fetus in the umbilical vein. From a dynamic perspective, this is impossible without a diastolic suctional force to augment the systolic contribution. Similarly, the diastolic dysfunction described above in adults is seen in the fetus manifesting as abnormal diastolic waveforms seen by Doppler velocimetry. An early diastolic suctional force in the heart has been demonstrated following delivery of the infant [111-115].

Since the introduction of the electrocardiogram in the early decades of the $20^{\text {th }}$ century scientists assumed that electrical currents flowing through the nerves along the outer surface of the heart caused the ventricles to contract despite the fact that the heart possesses intrinsic rhythmicity and continues to function in the absence of nerves. Nor did scientists consider what happens to the electrical currents seen on ECG after they ostensibly induce contraction of the heart. Do they vanish into thin air?

Evidence suggests that electron currents are drawn through the nerves by the contraction of the heart and infused directly into the blood. The excess of negative charge induces formed blood elements like proteins to repel which initiates active dilation during the succeeding diastolic phase. Those familiar with Faraday's Law will recognize that the spiral motion of the blood and its electrical currents generates an electromagnetic field which is distributed to cells and tissues throughout the body. There is not one but two circulations: one of flowing fluids, the other of flowing energy currents [120].

The notion of an organized blood-borne energy field is not new. It was first advanced by Roman physician Galen in the late $2^{\text {nd }}$ century $\mathrm{AD}$ and was accepted as fact by physicians for 1500 years until it was arbitrarily discarded by chemically oriented scientists and physicians in the $17^{\text {th }}$ and $18^{\text {th }}$ centuries. In Galen's humoral system of medicine, the energy and nutrient substances needed to drive all bodily functions came from the blood [121].

Deterioration of the heart-blood energy field forms the basis of numerous chronic diseases. A plethora of reports link diastolic dysfunction to coronary artery disease, chronic heartfailure and other cardiac conditions; diastolic dysfunction is associated with metabolic syndrome $\mathrm{X}$, first described in the 1980s, and the cluster of associated disturbances including hypertension, insulin resistance, diabetes, and obesity [122, 123]. Equally these chronic diseases reflect impaired energy generation in the blood and, as we will see, it is on this basis that the powerful effects of ozone PC are mediated.

\section{Ozone Preconditioning}

Hormesis is not a new concept. Roman poet Marcus Lucan introduced the term immunis, meaning exemption from duty or fate, in the $1^{\text {st }}$ century $\mathrm{AD}$ when writing of the legendary resistance of the African Psylli tribe to the effects of venomous snakebite. For centuries it was known that exposure to small doses of a toxin confers protection to subsequent larger amounts of it. During the 19th century homeopathic physicians recognized this principle at play in Jenner's introduction of vaccination. But description and explanation are two different things. In PC one comes face-to-face with the dynamics behind this long-established principle. And as in the case of molecular biologists, one cannot explain the PC phenomenon without invoking the presence of an organized energy field in the blood.

PC comprises two opposing aspects: the immediate consequences of the toxic assault and the protective response initiated by the body to counteract its noxious influence. A dramatic display of this PC effect is seen with ozone, possibly the most powerful PC agent yet discovered. Ozone's primary effect is induction of brief oxidative injury, especially on membrane lipids, which impairs mitochondrial energy generation and leads to formation of reactive oxygen and nitrate species which compound cellular injury. Such oxidative insults on the cell machinery trigger release of pro-inflammatory cytokines that elicit an immune response further aggravating cell damage. The cascade of events induces a self-amplifying spiral of deterioration in cells which is then counterpoised by an infusion of energy into the blood resulting in the first window of PC protection.

While ozone's effects are well known, its mechanism of action remains unclear. Ozone, triatomic oxygen, exists in various mesomeric (resonance) states and is 10-15X more soluble in water than is diatomic oxygen. Once in contact with bodily fluids it immediately solubilizes and effects are likely mediated via an induced resonance state in water, which accounts for the body-wide actions. While diatomic oxygen is an avid electron scavenger, dissolved ozone is an uber energy sink that draws electron-equivalents from biomolecules leaving them in an energy-poor oxidized state. This results in conversion of polyunsaturated fatty acids in plasma into various lipid oxidation products: lipoperoxyl radicals, hydroperoxides, malonyldialdehyde, and 4-hydroxy-2,3-transnonenal (HNE) and more [124127].

Molecular biologists claim that lipid oxidation products, especially HNE, pass throughout the body and act as 
messenger substances to turn on gene function and transcription of biomolecules which then counteract the injurious effects of ozone. But this explanation makes no sense. Ozone induces profound depletion of intracellular energy reserves with resultant mitochondrial dysfunction and build-up of free radical species. Given that gene transcription and protein synthesis are energy-requiring, from where does the energy come to carry out such constitutive processes? At this point the molecular account falls apart [128-131]. The PC response begins above the tissue level and has its origins in the blood.

Blood cells, in particular erythrocytes (RBCs), are the first to experience the oxidative effects of ozone and to mount a response. RBCs, highly metabolically active, form a large part of the intravascular compartment with an estimated mass of up to 2.3 kilograms. Upon contact with ozonated water, RBCs undergo a transient dosedependent decrease in energy flux, estimated to be in the $5-25 \%$ range over a period of $15-20$ minutes, and then respond with a rebound surge in energy release along with outpouring of antioxidants. Ozone induces up-regulation of glycolytic enzymes in RBCs with activation of the Krebs cycle, enhanced ATP synthesis, and production of NADPH reducing equivalents which spill into the blood and neutralize the oxidizing effects of ozonated water [132136].

Heightened energy output by the RBC mass translates directly into increased blood flow and energy delivery to peripheral tissues. RBCs possess the enzyme nitric oxide (NO) synthase and generate large amounts of NO in response to oxidative stress that not only increases RBC hardiness and deformability but interacts with endothelial-generated NO to maintain active vasodilation (a reliable proxy for blood energy content) [137-148]. Ozone-related oxidative stress triggers activation of hypoxia inducible factor-1 (HIF-1) which, in turn, augments release of vascular endothelial growth factor (VEGF) and erythropoietin (EPO) which stimulate angiogenesis, blood flow and oxygen delivery to peripheral tissues [149].

It is clear that the first phase of the PC response, aimed at generating increased blood energy levels, is responsible for orchestrating subsequent events at the cellular level. Energy currents, carried in the interstitial fluid space, enter cells via ion channel mechanisms and, in short order, enhance mitochondrial function and intracellular energy metabolism as well as inducing a plethora of genes that actively counteract oxidative stress. Equally clear is that the second window of protection is mainly driven by events at the cellular level as a result of gene induction. Critical response pathways include nuclear factor erythroid 2-related factor 2 (Nrf2) and the heme oxygenase-1 enzyme (HO-1) system.

The powerful antioxidant and anti-inflammatory effects unleashed throughout the body by low dose ozone administration are mediated through activation of the transcription factor $\mathrm{Nrf} 2$. Nrf2, master regulator of redox balance, binds to over 200 different genes, known as the antioxidant response element (ARE), and effects transcription of cytoprotective substances like heat shock proteins, antioxidant and detoxification molecules, enzymes involved in synthesis of glutathione, a host of growth factors like VEGF and EPO, and more. The Nrf2driven battery of gene products also effects breakdown and/or refolding of misfolded proteins, DNA repair, mitochondrial rebuilding, autophagy regulation, as well as intracellular metabolism. Impaired Nrf2 function is a hallmark of many chronic disease conditions [150-156].

This robust counter-response is facilitated by disassembly of the very cell from which the PC phenomenon originates: the RBC. Since its discovery in 1968 it was widely assumed that $\mathrm{HO}-1$ was involved solely in haemoglobin degradation and bilirubin metabolism but by the late 1980s, it was recognized that it is induced by factors that produce oxidative stress like ischemia, hyperthermia, endotoxins, heavy metals, and that it plays a role in the PC response and cell homeostasis. HO-1, with strong anti-inflammatory properties, regulates processes like apoptosis, cell proliferation, and angiogenesis. And bilirubin, long thought to be an inactive haemoglobin breakdown product, is now known to be a potent antioxidant [156-167]. It all comes full circle in the blood.

One of the most striking downstream effects of ozone PC is modulation of the inflammatory response. Intracellular inflammation is mediated by the NLRP3 inflammasome, a multiprotein complex that integrates stress signals from the extracellular fluid space, so-called pathogenand damage-associated molecular patterns, and internal stress signals such as reactive oxygen species related to mitochondrial dysfunction. Stress signals lead to NLRP3 activation with release of proinflammatory cytokines IL-1 $\beta$ and IL-18 and caspase-1 dependent apoptosis (programmed cell death). Ozone PC asserts antiinflammatory and anti-apoptotic effects via suppression of NLRP3 inflammasome activity. This effect can only be explained by the direct infusion of energy currents into mitochondria. Since abnormal inflammasome activation is a prominent feature of various chronic conditions like Alzheimer's, autoimmune disorders, cardiac and renal disease, as well as acute inflammatory syndromes like Covid-19, it has been suggested that ozone PC could modulate disease activity in these circumstances [168183].

\section{Ischemia-Reperfusion Injury}

Given the presence of a blood-borne energy field that drives all functional processes in the body, it stands to reason that oxidative injury and its deleterious consequences, or allied conditions like inflammation, 
must represent primary energy deficiency states. Equally, associated symptoms, the chest pain of angina pectoris or neurologic deficits of stroke for example, must be conceived along similar lines. To better understand the dynamics of the PC-associated corrective physiology we examine another common and unexplained phenomenon known as ischemia-reperfusion injury (IRI).

IRI, like PC, has been a topic of great interest in recent years. Reperfusion injury refers to a cascade of catastrophic events set into motion by impaired energy dynamics which arise because of attempts to intervene in dire clinical situations like myocardial infarct, stroke, or organ failure. In all cases, whether as a consequence of angioplasty, thrombolysis, surgical bypass, or

transplantation, a prolonged period of flow interruption between the vascular compartment and affected organ had been present and, upon reestablishment of flow, a cascade of adverse events ensues. While the cellular and molecular events related to IRI vary from organ to organ, underlying dynamics are the same. The primary dysfunction involves a maladaptive interplay between the vascular and intracellular fluid compartments [184-191].

The events associated with IRI are exactly those which PC is known to prevent: cell death, disruption of tissue viability and architecture, accumulation of fluid and/or blood in the tissue spaces, and loss of organ function. There are localizing biochemical abnormalities depending on which organ is affected. In the heart arrhythmias and contractile dysfunction often occur. The spiral of deterioration begins after blood flow has been re-established and, depending on the severity of injury, evolves over hours to days. IRI is said to occur in about $20-60 \%$ of rescue attempts depending on the type of intervention, involved organ, and preexisting status of the patient. The appearance of IRI counteracts any intended benefit of the procedure and, moreover, may precipitate organ failure or death.

IRI was first described in 1960 after prolonged coronary artery ligation in dogs [192]. Contrary to expectations, reperfusion seemed to accelerate the extent of heart damage. Histologic changes after 30-60 minutes of IR were similar in severity to those observed after 24 hours of permanent occlusion. For decades it remained controversial whether reperfusion of a blocked vessel caused tissue injury. Evidence now indicates it promotes additive damage upon pre-existing ischemic injury. There are no reliable pharmacologic therapies by which to lessen its effects.

In a 2005 study, after stents were deployed across occluded coronary artery segments, researchers applied a post-conditioning sequence using repetitive inflationdeflation cycles with a coronary angioplasty balloon and observed a $36 \%$ decrease in the size of the affected area [193]. Such results indicate that the effects of IRI can be mitigated. It also points to the fact that the beneficial effects of PC and the detrimental effects of IRI revolve around a single primary phenomenon: the disposition of energy. Many studies substantiate the effects of ozone PC in preventing or ameliorating IRI-induced tissue injury [194-224]. Studies support the equivalency of ozone PC and ischemic PC [225-226].

The distorted dynamics of IRI can, once again, be understood by distinguishing between events arising from the primary oxidative injury and corrective attempts originatingin thearteries andblood.Oncearterialocclusion occurs cells shift to anaerobic energy metabolism leading to intracellular acidosis and free radical generation. Given the inefficiencies of such pathways the longer the duration of ischemia the greater the extent of cell damage. Once blood flow into the ischemic zone is re-established the metabolism shifts rapidly in the opposite direction, from anaerobic back into aerobic pathways, often with disastrous consequences.

As oxygen/energy diffuses into cells there is rapid reversal of acidosis with elevation of $\mathrm{pH}$ and corresponding shifts in ion currents. But incomplete reduction of oxygen inside cells persists and produces more free radicals that overwhelm antioxidant pathways and further aggravate cell injury. Reactive oxygen species interact with lipids and proteins to generate toxic oxidative products that compound injury. Progressive deterioration of electrochemical gradients across cellular and mitochondrial membranes eventually leads to cell death. Events at the cellular level are only part of the chaos.

As flow returns to the energy-starved tissues a host of blood-borne processes are set into motion that exacerbate the situation. Endothelial cells lining the previously occluded arterial segments resume function and vascular permeability increases to allow passage of immune cells and mediator substances into tissues surrounding the infarct. Immune cells release more cytokines intensifying inflammation. Neutrophils and endothelial cells produce even more free radicals, vasoactive substances and adhesion molecules that worsen effects. The final insult of IRI is microvascular obstruction with stasis of blood flow, the so-called no-reflow phenomenon, in which flow into the ischemic zone ceases altogether due to adhesion of blood elements, vasoconstriction of arterioles, and collapse of the capillary bed due to interstitial edema [227].

The most significant determinants of IRI are duration of tissue ischemia [228-230] and the pre-existing state of the cardiovascular system [231-235]. IRI is more likely to occur and to be more severe in conditions like diabetes, hypertension, heart failure, the metabolic syndrome, as well as with increasing age, i.e., the same conditions in which PC is blunted or absent. 
The most consistent finding in IRI is microvascular dysfunction [236-244]. NO is a proxy for energy flux through the blood. Multiple reports link diminished NO with impaired dilation $[245,246]$. Decreased NO levels correlate with vasoconstriction during reperfusion [247]. But while mediating vasodilation, in the presence of extensive tissue injury NO serves as a source of free radicals which cause further damage [248-250]. During IRI there is disturbed endothelial function involving all small blood vessels - arterioles, capillaries and venules with impaired dilation and outward passage of fluid and immune cells along with decreased reabsorption of interstitial fluid by post-capillary venules. Such reports point to a distinct functional layer centered in the vascular compartment mediated by dilation, contraction and the flow of energy.

The detrimental consequences of IRI, like the beneficial effects of PC, are distributed throughout the vascular compartment: organ failure at one site can induce remote organ injury. A 2000 study found that prolonged intestinal ischemia with IRI induced microvascular dysfunction in the lungs with impaired alveolar-capillary functions and pulmonary hypertension [251]. Another study produced acute lung injury in rats by prolonged cross-clamping of the abdominal aorta [252]. Affected animals showed increased microvascular permeability and elevated proinflammatory cytokines. In a 2006 study IRI in the liver was associated with acute lung injury with alterations in NO levels and inflammatory cytokines [253]. IRI in the intestines triggered liver dysfunction with accumulation of leukocytes and inflammatory injury [254]. Another report found that IRI in the liver induced cardiac dysfunction [255]. All these adverse consequences are triggered by dysfunction originating in the energy field.

Microvascular dysfunction associated with IRI is prevented with preconditioning or lessened by postconditioning [256-261]. By 1993 evidence suggested that PC induced tolerance to the effects of IRI [262]. A 1994 study found that ischemic PC protected against coronary endothelial dysfunction associated with IRI [263]. Similar results were reported in 2003 [264]. Ischemic PC preserves intracellular ATP, enhances functional recovery, and coronary reflow during reperfusion [265]. A 2017 study found that remote PC protects against liver IRI through a NO-mediated mechanism, implicating an influx of energy into the vascular compartment [266]. Beneficial effects of ozone PC in experimentally-induced IRI have been shown in heart, lung, liver, kidneys, intestines, and ovaries.

How are all these diverse effects orchestrated unless influenced by a common effector substance? The conclusion is inescapable: PC and IRI are two sides of the same coin, their opposing effects mediated by the disposition of energy in the blood and interstitial fluid space. No definitive answer is to be found in the maze of cellular and molecular pathways.

\section{The Case for Ozone}

Having examined ozone PC we can distill principles with regard to its mechanism of action and speculate on various disease states that might be responsive to its effects: by inducing oxidative stress in RBCs it triggers a surge of energy in the blood which passes through the interstitial fluid space, across cell membranes, and into the cytoplasm where it directly stimulates mitochondrial metabolism and activates Nrf2, the transcription factor responsible for switching on hundreds of genes involved in the counter-response. Ozone PC induces a shift from anaerobic to aerobic metabolism, triggers release of free radical scavengers, shuts off pro-inflammatory cytokine signals, quells the immune response and, finally, activates intracellular repair and upbuilding processes. Quite an impressive résumé.

Accordingly, if we compile a list of candidate conditions for ozone PC, we would seek those associated with mitochondrial dysfunction and oxidative injury, those with pro-inflammatory cytokine signatures, and those with functional and symptomatic deficits attributable to defective energy generation. As it happens, that list is quite long and comprises many of the most commonly encountered entities, both acute and chronic, seen in modern clinical practice. And, unfortunately, that expansive list is closely linked to the failure of $20^{\text {th }}$ century medical science to address energy dynamics in the blood.

Over the past 40 years there has been a global explosion of chronic conditions unparalleled in recorded human history: diabetes, obesity, hypertension, the metabolic syndrome, chronic organ failure syndromes involving heart, kidneys and liver, autoimmune disorders, neurodegenerative diseases like Alzheimer's, Parkinson's, Huntington's and amyotrophic lateral sclerosis, a host of chronic pain syndromes, chronic asthma and allergic conditions and a litany of others. Some regard this epidemic of epidemics as the fallout of industrialization, others as the human accompaniment of climate change. In any event, medical science, to date, is neither able to prevent nor alter their progression. Not only is ozone PC effective in a wide range of chronic disease states but in acute infectious conditions like Covid-19.

A 2019 review of ozone treatment in acute infectious disease concluded that it is effective in either adjunctive or stand-alone modes. Ozone has virtually no side effects and does not induce microbial resistance patterns like pharmacologic therapies [267]. Numerous studies affirm ozone's efficacy and safety in Covid-19 disease [267-281]. Thorp et al. describe mechanisms by which ozone therapy affects Covid-19 outcomes: increased antioxidant production, induction of Nrf2- and $\mathrm{HO}-$ 1-mediated nuclear mechanisms, down-regulation of pro-inflammatory immune pathways, direct toxic viral 
effects, inhibition of viral replication and increased blood and tissue oxygenation [279]. Various reports suggest that ozone's capacity to stimulate immune function, modulate inflammation and suppress viral activity augur a whole new therapeutic paradigm [280].

Ozone therapy reduced viral titers and improved clinical symptoms in Covid-19-infected ICU patients [280]. Other studies found that ozone shortened time-lines for clinical improvement [281]. Since ozone confers protection against organ-injury in ischemia-reperfusion injury it only stands to reason that it should prevent or mitigate multi-system organ failure associated with advanced Covid-19 infection if administered in a time-sensitive manner. Given its widespread availability and negligible cost it is utterly baffling why medical scientists failed to implement ozone therapy during the Covid-19 pandemic; ozone and drugs like hydroxychloroquine, ivermectin, and others have been widely used to effectively treat Covid-19 in outpatient settings. Undoubtedly such a strategy would have saved countless lives. It is predictable that this catastrophic oversight will become the subject of great controversy in coming years.

In that autoimmune disease is defined by chronic recurrent inflammatory episodes involving organs and tissues and characterized by similar dynamics as acute inflammation, i.e., activation of the immune system, elevated levels of pro-inflammatory cytokines, mitochondrial dysfunction and oxidative stress at the cellular level, it would be expected that they too would be ideal candidates for ozone PC [282-291]. A handful of clinical reports confirm its efficacy in multiple sclerosis with down-regulation of the pro-inflammatory state and amelioration of oxidative stress [33-38][292-294]. Similar results have been obtained in laboratory experiments with animal models of rheumatoid arthritis and psoriasis [282287], and with fibromyalgia [295-301]. Although data is limited, given the presence of mitochondrial dysfunction, oxidative injury, and inflammation in affected neuronal populations in the neurodegenerative disorders [302305], it would seem that these conditions too would be suitable candidates for ozone PC.

In the previous section we described the powerful effects of PC in preventing or mitigating ischemia-reperfusion injury in various organs including the kidneys, heart, liver and lungs suggesting the potential of ozone therapy in stabilization or reversal of organ failure syndromes. Many studies document the benefits of ozone PC in improving kidney function in a wide range of pathologic states [175][306-320]. Ozone reduces lithotripsy shock wave therapy-induced renal injury [333]; reduces renal inflammation [335], reduces inflammation and renal injury in acetaminophen-induced nephrotoxicity [313]; improves acute nephrotoxicity induced by cisplatin [319], and; attenuates contrast-induced nephropathy [311].

By the same token the protective effects of ozone PC on liver function in ischemia-reperfusion injury suggest its potential in the treatment of various chronic hepatic conditions that to date are largely refractory to current medical therapies like non-alcoholic fatty liver disease, chronic hepatitis and early forms of cirrhosis [321-327]. The incidence of fatty liver disease has exploded in recent decades and it is now a leading cause of hepatic failure and subsequent transplantation. Ozone has been used successfully in a large number of infectious diseases and has been shown to significantly reduce viral loads in Covid-19 as noted above but is also effective in other viral infections including hepatitis $\mathrm{C}$, hepatitis A, and HIV [267][321-326].

A similar argument can be made for its use in the global epidemic of chronic heart failure [329-331], a leading cause of hospitalization in people over sixty years of age. No pharmacologic treatments prevent the insidious and progressive deterioration of heart function in those affected. Given that oxidative stress and mitochondrial dysfunction drive airway inflammation in chronic obstructive pulmonary disease, it seems that ozone PC could play a role in mitigation of pulmonary symptoms in such cases [331, 332].

The explosion of diabetes and the metabolic syndrome over the past four decades has radically changed the health care landscape and the need for new, effective and low-cost treatments has never been greater. Undoubtedly diabetes and the metabolic syndrome originate in the blood as a result of deterioration of its energy field. It is well-known that the PC response is blunted or absent in diabetes and the metabolic syndrome. To our knowledge no studies have directly examined the effect of ozone PC on the underlying disease conditions but multiple reports describe beneficial effects on diabetic foot ulcers and skin wounds which are often refractory to current therapies.

Diabetic ulcers, now seen with increasing frequency, are multifactorial in nature and attributable a host of overlapping factors like coexisting vascular disease, peripheral neuropathy, immunologic abnormalities and superimposed infection. Multiple reports document beneficial effects of ozone therapy on both diabetic and non-diabetic wound healing [333-343]. Ozone promotes healing of diabetic ulcers by modulating all the various contributing factors: enhancing blood flow through nitric oxide induced endothelial dilation, increasing energy flow through peripheral nerves, shifting the immune response toward anti-inflammatory pathways and curbing infection. Lesions are treated with topical ozonated oils, ozone 'tents' and intravenously [344-348].

Ozone PC has been used to treat a wide array of acute and chronic skin wounds beyond diabetic ulcers including bed sores, post-traumatic ulcers, burns, chronic viral infections like human papilloma virus and herpes, vaginal infections related to candida, trichomonas and chlamydia 
overgrowth, rectal abscesses and fistulas, as well as oral aphthous ulcers [344-348]. In their systematic review of ozone treatment in chronic wounds Fitzpatrick et al. found significant improvements in healing and wound closure [344]. In other studies using animal models researchers found increased numbers of fibroblasts and collagen deposition as well as humoral factors like VEGF and transforming growth factor- $\beta$ suggesting accelerated healing responses [343, 346].

An increasing number of reports document the effectiveness of ozone PC for pain relief in a variety of chronic conditions including low back pain related to disc herniation, degenerative disc disease, sciatica, failed back surgery, as well as post-traumatic, inflammatory, and degenerative joint pain [19-28][349-366]. In such cases ozone has been injected directly into the disc space, neural foramen or joint capsule. In a large outcome study of 2900 patients with lower back pain and sciatica, Muto et al. [365] found that intra-discal and intra-foraminal ozone administration was a safe and efficacious means of treating low back pain. Other studies suggest that symptom relief with ozone was greater than with conventional steroid injections.

In these various chronic pain conditions ozone PC appears to assert its effects through the same means we have already highlighted: enhanced RBC-driven generation of blood-borne energy, increased endothelial-dependent vasodilation and blood flow into the microcirculation, increased oxygen delivery to the tissues, optimization of mitochondrial function with reduction of intracellular stress, and down-regulation of inflammation. The diminished pain perception reported in so many studies can only be attributed to increased energy currents through sensory nerves. On what another basis can this be explained?

The great advantage of ozone lies not only in its ability to trigger energy generation in the blood but in its simple means of production and ridiculously low cost. Just as early scientists scented its presence in the air following lightning strikes, ozone can literally be produced anywhere there is an oxygen source and an appropriate voltage gradient. Its ease of administration and wide variety of potential routes puts many pharmacologic substances to shame: intramuscular, subcuticular, intra-articular, direct intravenous injection, infusion of ozonated-saline, rectal / bladder / vaginal insufflation, trigger point injections, and others [19-28][327-348] [267][295][305].

In addition to its remarkable and durable track record in improving clinical and laboratory parameters in a wide range of acute and chronic disease, ozone has been shown in many clinical studies to have virtually no side effects when administered along established dosing guidelines. It is not hyperbole to say it is far safer than most over-the-counter medicines now available. Given the overwhelming evidence it is not only bewildering but profoundly distressing to observe the numerous attempts in recent years by various oversight agencies to restrict and suppress the use of ozone by health practitioners and the general public as a preventive and therapeutic modality [369-376].

This is particularly relevant given a 2016 study by Makary and Daniel [377] in BMJ which found that medical errors in US hospitals accounted for approximately 252,000 deaths annually making it the third leading cause of death. Another epidemiologic study reported by Lazarou et al. [378] in JAMA suggests that drug-related deaths may account for up to $50 \%$ of this burden. Along these lines we would be remiss if we failed to point out that since the beginning of the $20^{\text {th }}$ century when the modern therapeutic era was inaugurated medical science has yet to cure a single class of disease. Ozone PC may be its last chance to finally get things right.

\section{Paradigm Shift}

In his ground-breaking work The Structure of Scientific Revolutions (1962) science historian Thomas Kuhn points to an under-appreciated aspect of experimental science: as discoveries are made and new facts come to light, the nature of scientific knowledge must change in accordance with those new facts. Science is fundamentally an evolutionary (and revolutionary) undertaking. Kuhn coined the term 'paradigm' to refer to an explanatory theory and its allied methods and practices. The entire history of the experimental sciences is little more than a series of boom-bust cycles characterized by the rise and fall of successive paradigms. The collapse of an existing paradigm is always heralded by its inability to explain the nature of new facts.

Since the beginning of the $20^{\text {th }}$ century medical science has based all its theories on data derived from the molecular and cellular layers of process. During this time causal explanations have come and gone with striking frequency because molecular and cellular processes are not the only events that transpire inside the body. Molecular and cellular accounts describe but do not explain. The only convincing explanation for the described phenomena is the presence of a blood-borne energy field.

The discovery of the primacy of the diastolic phase of the cardiac cycle (and collapse of the systolic-based heart model) along with the recognition of the preconditioning phenomenon in the $1980 \mathrm{~s}$ upended the $20^{\text {th }}$ century molecular-cellular paradigm. The subsequent recognition of ozone as the most powerful preconditioning agent yet discovered was only the straw that broke the camel's back. In this sense we can say that the current biomedical paradigm no longer exists as a conceptual reality nor does it have therapeutic relevance. 
The new blood-borne energy-based dynamic paradigm and its allied concept of preconditioning with substances like ozone must now come to the forefront and not only replace the decayed molecular-cellular paradigm but attempt to repair and reverse the incalculable damage inflicted by this obsolete perspective. The king is dead, long live the king!

\section{References}

1. Calabrese EJ. Historical foundations of hormesis. Homeopathy. 2015 Apr;104(2):83-9.

2. Calabrese EJ, Baldwin LA. The marginalization of hormesis. Hum Exp Toxicol. 2000 Jan;19(1):3240.

3. Maehle AH. The quantification and differentiation of the drug receptor theory, c. 1910-1960. Ann Sci 2005 Oct;62(4):479-500.

4. Szabadi E. A model of two functionally antagonistic receptor populations activated by the same agonist. J Theor Biol. 977 Nov 7;69(1):101-12.

5. Calabrese EJ, Baldwin LA. Chemical hormesis: its historical foundations as a biological hypothesis. Hum Exp Toxicol. 2000 Jan;19(1):2-31.

6. Calabrese EJ, Baldwin LA. Hormesis: a generalizable and unifying hypothesis. Crit Rev Toxicol. 2001 Jul;31(4-5):353-424.

7. Calabrese EJ. The maturing of hormesis as a credible dose-response model. Nonlinearity Biol Toxicol Med. 2003 Jul;1(3):319-43.

8. Calabrese EJ, Baldwin LA. Hormesis: The dose-response revolution. Annu Rev Pharmacol Toxicol. 2003;43:175-97

9. Calabrese EJ. Hormesis and medicine. Br J Clin Pharmacol. 2008 Nov;66(5):594-617.

10. Calabrese EJ. Hormesis: Path and Progression to Significance. Int J Mol Sci 2018 Sep 21;19(10). pii: E2871.

11. Rivas-Arancibia S, Vazquez-Sandoval R, Gonzalez-Kladiano D et al. Effects of ozone exposure in rats on memory and levels of brain and pulmonary superoxide dismutase. Environ Res 1998.76, $33-39$.
12. Avila-Costa MR, Colin-Barenque L, Fortoul TI, et al. Memory deterioration in an oxidative stress model and its correlation with cytological changes on rat hippocampus cal. Neurosci Lett.1999, 270, 107-109.

13. Gackière F, Saliba L, Baude A, et al. Ozone inhalation activates stress-responsive regions of the CNS. J Neurochem. 2011;117: 961-972.

14. Mumaw CL, Levesque S, McGraw C, Robertson S et al. Microglial priming through the lung-brain axis: The role of air pollution-induced circulating factors. FASEB 2016; 30:1880-1891.

15. Niu Z, Liu F, Yu H, Wu S, Xiang H. Environ Health Prev Med. Association between exposure to ambient air pollution and hospital admission, incidence, and mortality of stroke: an updated systematic review and meta-analysis of more than 23 million participants. 2021 Jan 26;26(1):15.

16. Wang Z, Peng J, Liu P, Duan Y et al. Association between short-term exposure to air pollution and ischemic stroke onset: a time-stratified case-crossover analysis using a distributed lag nonlinear model in Shenzhen, China. Environ Health 2020 Jan 2;19(1):1.

17. Tian Y, Liu H, Zhao Z, Xiang X, et al. Association between ambient air pollution and daily hospital admissions for ischemic stroke: A nationwide time-series analysis. PLoS Med 2018 Oct;15(10):e1002668.

18. Henrotin JB, Besancenot JP, Bejot Y, Giroud M. Short-term effects of ozone air pollution on ischaemic stroke occurrence: a case-crossover analysis from a 10-year population-based study in Dijon, France. Occup Environ Med. 2007 Jul;64(7):43945.

19. Fuccio C, Luongo C, Capodanno $P$ et al. A single subcutaneous injection of ozone prevents allodynia and decreases the over-expression of pro-inflammatory caspases in the orbito-frontal cortex of neuropathic mice. Eur J Pharm. 2009,603,4249.

20. Lu L, Pan C, Chen L, Hu L et al. AMPK activation by peri-sciatic nerve administration of ozone attenuates CCI-induced neuropathic pain in rats. Mol 
Cell Biol. 2017 Apr;9(2):132-143.

21. Luo WJ, Yang F, Yang F, Sun W et al. Intervertebral Foramen Injection of Ozone Relieves Mechanical Allodynia and Enhances Analgesic Effect of Gabapentin in Animal Model of Neuropathic Pain. Pain Physician 2017 Jul;20(5):E673-E685.

22. de Sire A, Baricich A, Minetto MA, Cisari C, Invernizzi M. Low back pain related to a sacral insufficiency fracture: role of paravertebral oxygen-ozone therapy in a paradigmatic case of nociplastic pain. Funct Neurol 2019 Apr/Jun;34(2):119-122.

23. The effect and safety of ozone autohemotherapy combined with pharmacological therapy in postherpetic neuralgia. $\mathrm{Hu} \mathrm{B}$, Zheng J, Liu Q, Yang Y, Zhang Y J Pain Res 2018 Aug 27;11:1637-1643.

24. Barbosa DC, Ângelos JSD, Macena GMJ, et al. Effects of ozone on the pain and disability in patients with failed back surgery syndrome. Rev Assoc Med Bras. 2017 Apr;63(4):355-360.

25. Gao L, Chen RW, Williams JP, Li T, et al. Efficacy and Safety of Percutaneous Ozone Injection Around Gasserian Ganglion for the Treatment of Trigeminal Neuralgia: A Multicenter Retrospective Study. J Pain Res. 2020 May 4;13:927-936.

26. Magalhães FN, Soares SC, Torres JM, Ungaretti A, et al. Effects of ozone applied by spinal endoscopy in patients with chronic pain related to failed back surgery syndrome: a pilot study. Neuropsychiatr Dis Treat. 2013;9:1759-66.

27. Crockett MT, Moynagh M, Long N, Kilcoyne A, et al. Ozone-augmented percutaneous discectomy: a novel treatment option for refractory discogenic sciatica. Clin Radiol. 2014 Dec;69(12):1280-86.

28. Bonetti M, Fontana A, Albertini F. CT-guided oxygen-ozone treatment for first degree spondylolisthesis and spondylolysis. Acta Neurochir Suppl. 2005;92:87-92.

29. Wasser G. Ischemic stroke penumbra and extracorporeal ozone treatment. Neuroradiol J. 2013 Jun;26(3):243-51.j

30. Frosini M, Contartese A, Zanardi I, Travagli V, Bocci V. Selective ozone concentrations may reduce the ischemic damage after a stroke. Free Rad
Res 2012 May;46(5):612-8.

31. Clavo B, Suarez G, Aguilar Y et al. Brain ischemia and hypometabolism treated by ozone therapy. Forsch Komplementmed. 2011;18(5):283-7.

32. Wu X, Liu X, Huang H, Li Z et al. Effects of major ozonated autoheamotherapy on functional recovery, ischemic brain tissue apoptosis and oxygen free radical damage in the rat model of cerebral ischemia. J Cell Biochem. 2019 Apr;120(4):67726780 .

33. Izadi M, Tahmasebi S, Pustokhina I, et al. Changes in Th17 cells frequency and function after ozone therapy used to treat multiple sclerosis patients. Mult Scler Relat Disord 2020 Nov;46:102466.

34. Ameli J, Banki A, Khorvash F, Simonetti V. Mechanisms of pathophysiology of blood vessels in patients with multiple sclerosis treated with ozone therapy: a systematic review. Acta Biomed 2019 Sep;90(3):213-217

35. Travagli V. The right method of ozone therapy used to treat multiple sclerosis patients. Mult Scler Relat Disord. 2020 Nov;46:102545.

36. Tahmasebi S, Qasim MT, Krivenkova MV, Zekiy $\mathrm{AO}$ et al. The effects of oxygen-ozone therapy on regulatory $\mathrm{T}$-cell responses in multiple sclerosis patients. Cell Biol Int. 2021 Mar.

37. Delgado-Roche L, Riera-Romo M, Mesta F, Hernández-Matos Y, et al. Medical ozone promotes Nrf2 phosphorylation reducing oxidative stress and pro-inflammatory cytokines in multiple sclerosis patients. Eur J Pharmacol. 2017 Sep 15;811:148-154.

38. Zhang SY, Gui LN, Liu YY, Shi S, Cheng Y. Oxidative Stress Marker Aberrations in Multiple Sclerosis: A Meta-Analysis Study. Front Neurosci. 2020 Aug 26;14:823.

39. Murry CE, Jennings RB, Reimer KA. Preconditioning with ischemia: a delay of lethal cell injury in ischemic myocardium. Circulation.1986 Nov;74(5):1124-36.

40. Schott RJ, Rohmann S, Braun ER, Schaper W. Ischemic preconditioning reduces infarct size in swine myocardium. Circ Res.1990 Apr;66(4):1133-42. 
41. Hagar JM, Hale SL, Kloner RA. Effect of preconditioning ischemia on reperfusion arrhythmias after coronary artery occlusion and reperfusion in the rat. Circ Res.1991 Jan;68(1):61-8.

42. Jennings RB, Murry CE, Reimer KA. Preconditioning myocardium with ischemia. Cardiovasc Drugs Ther. 1991 Oct;5(5):933-8.

43. Gross GJ, Auchampach JA. Blockade of ATP-sensitive potassium channels prevents myocardial preconditioning in dogs. Circ Res. 1992 Feb;70(2):223-33.

44. Asimakis GK, Inners-McBride K, Medellin G, Conti VR.Ischemic preconditioning attenuates acidosis and postischemic dysfunction in isolated rat heart. Am J Physiol.1992 Sep;263(3 Pt 7):H887-94.

45. Richard V, Kaeffer N, Tron C, Thuillez C. Ischemic preconditioning protects against coronary endothelial dysfunction induced by ischemia and reperfusion. Circulation 1994 Mar;89(3):1254-61.

46. Reimer KA, Heide RSV, Jennings RB. Ischemic Preconditioning Slows Ischemic Metabolism and Limits Myocardial Infarct Size. Ann NY Acad Sci. 1994 Jun;723(1):99-115.

47. Parratt J, Vegh A, Cardiosci. Pronounced antiarrhythmic effects of ischemic preconditioning.1994 Mar;5(1):9-18.

48. Gürke L, Marx A, Sutter PM et al. Ischemic preconditioning improves postischemic function, but not energy metabolism of skeletal muscles. Swiss Surg. 1995;(2):107-9.

49. Finegan BA, Lopaschuk GD, Gandhi M, Clanachan AS. Ischemic preconditioning inhibits glycolysis and proton production in isolated working rat hearts. Am J Physiol.1995 Nov;269(5 Pt 2):H1767-75.

50. Przyklenk K, Bauer B, Ovize M, Kloner RA, Whittaker P. Regional ischemic 'preconditioning' protects remote virgin myocardium from subsequent sustained coronary occlusion. Circulation. 1993 Mar;87(3):893-9.

51. Birnbaum Y, Hale SL, Kloner RA. Ischemic pre- conditioning at a distance: reduction of myocardial infarct size by partial reduction of blood supply combined with rapid stimulation of the gastrocnemius muscle in the rabbit. Circulation. 1997 Sep 2.96(5);1641-6.

52. Takaoka A, Nakae I, Mitsunami K, Yabe T, Morikawa S, Inubushi T, Kinoshita $M$. Renal ischemia/reperfusion remotely improves myocardial energy metabolism during myocardial ischemia via adenosine receptors in rabbits: effects of "remote preconditioning". J Am Coll Cardiol. 1999 Feb;33(2):556-64.

53. Cochrane J, Williams BT, Banerjee A, Harken AH, Burke TJ, Cairns CB, Shapiro JI. Ischemic preconditioning attenuates functional, metabolic, and morphologic injury from ischemic acute renal failure in the rat. Ren Fail. 1999 Mar;21(2):135-45.

54. Pang CY, Yang RZ, Zhong A, Xu N, Boyd B, Forrest $\mathrm{CR}$. Acute ischaemic preconditioning protects against skeletal muscle infarction in the pig. Cardiovasc Res.1995 Jun;29(6):782-8.

55. Soncul H, Oz E, Kalaycioglu S. Role of ischemic preconditioning on ischemia-reperfusion injury of the lung. Chest.1999 Jun;115(6):1672-7.

56. Stagliano NE, Pérez-Pinzón MA, Moskowitz MA, Huang PL. J Cereb Blood Flow Metab Focal ischemic preconditioning induces rapid tolerance to middle cerebral artery occlusion in mice. 1999 Jul;19(7):757-61.

57. Riera M, Herrero I, Torras J, Cruzado JM, Fatjo M, Lloberas N, Alsina J, Grinyo JM. Ischemic preconditioning improves postischemic acute renal failure. Transplant Proc. 1999;31(6):2346-7.

58. Pérez-Pinzón MA, Alonso O, Kraydieh S, Dietrich WD. Induction of tolerance against traumatic brain injury by ischemic preconditioning. Neuroreport. 1999 Sep 29;10(14):2951-4.

59. Nilsson B, Friman S, Gustafsson BI, Delbro DS. Preconditioning protects against ischemia/reperfusion injury of the liver. J Gastrointest Surg. 2000 Jan-Feb;4(1):44-9.

60. Hepatic preconditioning preserves energy metabolism during sustained ischemia. Peralta C, 
Bartrons R, Riera L, Manzano A, Xaus C, Gelpí E, Roselló-Catafau J Am J Physiol Gastrointest Liver Physiol. 2000 Jul;279(1):G163-71

61. Wang Y, Xu H, Mizoguchi K, Oe M, Maeta H. Intestinal ischemia induces late preconditioning against myocardial infarction: a role for inducible nitric oxide synthase. Cardiovasc Res. 2001 Feb $1 ; 49(2): 391-8$

62. Raeburn CD, Cleveland JC Jr, Zimmerman MA, Harken AH. Organ preconditioning. Arch Surg 2001 Nov;136(11):1263-6.

63. Bonventre JV. Kidney ischemic preconditioning Curr Opin Nephrol Hypertens. 2002 Jan;11(1):438.

64. Rejdak R, Rejdak K, Sieklucka-Dziuba M, Stelmasiak Z, Grieb P. Brain tolerance and preconditioning. . Pol J Pharmacol. 2001 Jan-Feb;53(1):73-9.

65. Aksöyek S, Cinel I, Avlan D, Cinel L, Oztürk C, Gürbüz P, Nayci A. Oral UIntestinal ischemic preconditioning protects the intestine and reduces bacterial translocation. Shock 2002 Nov;18(5):476-80.

66. Lu EX, Chen SX, Hu TH, Xui LM, Yuan MD. Preconditioning enhances myocardial protection in patients undergoing open heart surgery. Thorac Cardiovasc Surg.1998 Feb;46(1):28-32.

67. Dickson EW, Reinhardt CP, Renzi FP, Becker RC, Porcaro WA, Heard SO. Ischemic preconditioning may be transferable via whole blood transfusion: preliminary evidence. J Thromb Thrombolysis. 1999 Aug;8(2):123-9.

68. Dickson EW, Lorbar M, Porcaro WA, Fenton RA, Reinhardt CP, Gysembergh A, Przyklenk K. Rabbit heart can be "preconditioned" via transfer of coronary effluent. Am J Physiol 1999 Dec;277(6):H2451-7.

69. Dickson EW, Porcaro WA, Fenton RA, Heard SO, Reindhardt CP, Renzi FP, Przyklenk $\mathrm{K}$."Preconditioning at a distance" in the isolated rabbit heart. Acad Emerg Med. 2000 Apr;7(4):3117.

70. Liu X, Engelman RM, Moraru II, Rousou JA, Fla- ck JE 3rd, Deaton DW, Maulik N, Das DK. Heat shock. A new approach for myocardial preservation in cardiac surgery. Circulation 1992 Nov;86(5 Suppl):II358-63.

71. Domenech R, Macho P. Non-ischemic myocardial preconditioning. Mol Cell Biochem 1998 Sep;186(1-2):201-3.

72. Zdrenghea D, Ilea M, Predescu D, Potâng E. Ischemic preconditioning during successive exercise testing. Rom J Intern Med. 1998 Jul-Dec;36(3-4):161-5.

73. Miyamae M, Diamond I, Weiner MW, Camacho SA, Figueredo VM. Regular alcohol consumption mimics cardiac preconditioning by protecting against ischemia-reperfusion injury. Proc Natl Acad Sci USA 1997 Apr 1;94(7):3235-9.

74. Laghi Pasini F, Capecchi PL, Acciavatti A, Petri S, de Lalla A, Cati G, Colafati M, Di Perri T. Pharmacological preconditioning of ischaemia. Clin Hemorheol Microcirc. 1997 Jan-Feb;17(1):73-84

75. Tritto I, D’Andrea D, Eramo N, Scognamiglio A, De Simone C, Violante A, Esposito A, Chiariello $M$, Ambrosio G. Oxygen radicals can induce preconditioning in rabbit hearts. Circ Res 1997 May;80(5):743-8.

76. Zarro DL, Palanzo DA, Sadr FS. Myocardial preconditioning using adenosine: review and clinical experience. Perfusion. 1998 Mar;13(2):145-50.

77. Ito $\mathrm{H}$, Shimojo $\mathrm{T}$, Fujisaki $\mathrm{H}$, Tamamori M, Ishiyama S, Adachi S, Abe S, Marumo F, Hiroe M. Thermal preconditioning protects rat cardiac muscle cells from doxorubicin-induced apoptosis. Life Sci 1999;64(9):755-61.

78. Ikeda T, Xia XY, Xia YX, Ikenoue T. Hyperthermic preconditioning prevents blood-brain barrier disruption produced by hypoxia-ischemia in newborn rat. Brain Res Dev Brain Res. 1999 Oct 20;117(1):53-8.

79. Ozveri ES, Bekraki A, Cingi A, Yuksel M, Demiralp EE, Yegen BC, Aktan AO. The effect of hyperthermic preconditioning on the immune system in rat peritonitis. Intensive Care Med 1999 Oct;25(10):1155-9. 
80. Yang CW, Li C, Jung JY, Shin SJ, Choi BS, Lim SW, Sun BK, Kim YS, Kim J, Chang YS, Bang BK. Preconditioning with erythropoietin protects against subsequent ischemia-reperfusion injury in rat kidney. FASEB 2003 Sep;17(12):1754-5.

81. Bienengraeber MW, Weihrauch D, Kersten JR, Pagel PS, Warltier DC. Cardioprotection by volatile anesthetics. Vascular Pharmacol. 2005 Apr-May;42(5-6):243-52.

82. Ding YH, Li J, Yao WX, Rafols JA, Clark JC, Ding Y. Exercise preconditioning upregulates cerebral integrins and enhances cerebrovascular integrity in ischemic rats. Acta Neuropathol. 2006 Jul;112(1):74-84.

83. Ding YH, Mrizek M, Lai Q, Wu Y, Reyes R Jr, Li J, Davis WW, Ding Y. Exercise preconditioning reduces brain damage and inhibits TNF-alpha receptor expression after hypoxia/reoxygenation: an in vivo and in vitro study. Curr Neurovasc Res. 2006 Nov;3(4):263-71.

84. Kavazis AN. Exercise preconditioning of the myocardium. Sports Med.2009;39(11):923-35.

85. Wu X, Qian Z, Ke Y, Du F, Zhu L, Ginkgolide B. Preconditioning protects neurons against ischemia-induced apoptosis. J Cell Mol Med. 2009 Nov-Dec;13(11-12):4474-83.

86. Liu Y, Xue F, Liu G, Shi X, Liu Y, Liu W, Luo X, Sun $\mathrm{X}$, Kang Z. Helium preconditioning attenuates hypoxia/ischemia-induced injury in the developing brain. Brain Res. 2011 Feb;1376:122-9.

87. Koronowski KB, Dave KR, Saul I, Camarena V, Thompson JW, Neumann JT, Young JI, Perez-Pinzon MA.Resveratrol. Preconditioning Induces a Novel Extended Window of Ischemic Tolerance in the Mouse Brain. Stroke. 2015 Aug;46(8):22938.

88. Gidday JM. Pharmacologic preconditioning: translating the promise. Transl Stroke Res. 2010 Jan 3;1(1):19-30

89. Infarct limitation of the second window of protection in a conscious rabbit model. Yang XM, Baxter GF, Heads RJ, Yellon DM, Downey JM, Cohen MV. Cardiovasc Res 1996 May;31(5):777-83
90. Yamashita N, Hoshida S, Taniguchi N, Kuzuya T, Hori M. A "second window of protection" occurs $24 \mathrm{~h}$ after ischemic preconditioning in the rat heart. J Mol Cell Cardiol. 1998;30(6):1181-9.

91. Pagliaro P, Gattullo D, Rastaldo R, Losano G.Ischemic preconditioning: from the first to the second window of protection. Life Sci. 2001 May 25;69(1):1-15.

92. Kin H, Zhao ZQ, Sun HY, Wang NP, Corvera JS, Halkos ME, Kerendi F, Guyton RA, Vinten-Johansen J. Postconditioning attenuates myocardial ischemia-reperfusion injury by inhibiting events in the early minutes of reperfusion. Cardiovasc Res 2004 Apr 1;62(1):74-85.

93. Galagudza M, Kurapeev D, Minasian S, Valen G, Vaage J. Ischemic postconditioning: brief ischemia during reperfusion converts persistent ventricular fibrillation into regular rhythm. Eur J Cardiothoracic Surg 2004 Jun;25(6):1006-10.

94. Hahn CD, Manlhiot C, Schmidt MR, Nielsen TT, Redington AN. Remote ischemic per-conditioning: a novel therapy for acute stroke? Stroke. 2011 Oct;42(10):2960-2.

95. Vinten-Johansen J, Shi W. Preconditioning and postconditioning: current knowledge, knowledge gaps, barriers to adoption, and future directions. J Cardiovasc Pharmacol Ther. 2011 Sep-Dec;16(3-4):260-6.

96. Vander Heide RS, Reimer KA, Jennings RB. Adenosine slows ischaemic metabolism in canine myocardium in vitro: relationship to ischaemic preconditioning. Cardiovasc Res. 1993 Apr; 27(4):669-73.

97. Li Y, Kloner RA. The cardioprotective effects of ischemic 'preconditioning' are not mediated by adenosine receptors in rat hearts. Circulation. 1993 May;87(5):1642-8.

98. Tritto I, D’Andrea D, Eramo N, Scognamiglio A, De Simone C, Violante A, Esposito A, Chiariello M. Ambrosio G. Oxygen radicals can induce preconditioning in rabbit hearts. Circ Res. 1997 May;80(5):743-8.

99. Richard V, Tron C, Thuillez C. Ischaemic pre- 
conditioning is not mediated by oxygen derived free radicals in rats. Cardiovasc Res. 1993 Nov;27(11):2016-21.

100. Bolli R, Manchikalapudi S, Tang XL, et al. The protective effect of late preconditioning against myocardial stunning in conscious rabbits is mediated by nitric oxide synthase. Evidence that nitric oxide acts both as a trigger and as a mediator of the late phase of ischemic preconditioning. Circ Res 1997 Dec;81(6):1094-107.

101. Thornton JD, Thornton CS, Sterling DL, Downey JM. Blockade of ATP-sensitive potassium channels increases infarct size but does not prevent preconditioning in rabbit hearts. Circ Res.1993 Jan;72(1):44-9.

102. Liu Y, Sato T, O'Rourke B, Marban E. Mitochondrial ATP-dependent potassium channels: novel effectors of cardioprotection? Circulation. 1998 Jun 23;97(24):2463-9.

103. Gidday JM, Shah AR, Maceren RG et al. Nitric oxide mediates cerebral ischemic tolerance in a neonatal rat model of hypoxic preconditioning. Cereb Blood Flow Metab 1999 Mar;19(3):33140.

104. Lochner A, Genade S, Tromp E et al. Ischemic preconditioning and the beta-adrenergic signal transduction pathway. Circulation 1999 Aug;100(9):958-66.

105. Dawson TM. Preconditioning-mediated neuroprotection through preconditioning? Lancet 2002 Jan;359(9301):96-7.

106. Tanaka M, Fujiwara H, Yamasaki K et al. Expression of heat shock protein after ischemic preconditioning in rabbit hearts. Jpn Circ J. 1998 Jul;62(7):512-6.

107. Calabrese EJ. Preconditioning is hormesis part I: Documentation, dose-response features and mechanistic foundations. Pharmacol Res. 2016;110 242-264.

108. Calabrese EJ. Preconditioning is hormesis part II: How the conditioning dose mediates protection: Dose optimization within temporal and mechanistic frameworks. Pharmacol Res.
$2016 ; 110 ; 265-275$.

109. Sabbah HN, Anbe DT, Stein PD. Negative intraventricular diastolic pressure in patients with mitral stenosis: evidence of left ventricular diastolic suction. Am J Cardiol 1980; 45(3): 562-66.

110. Hori M, Yellin EL, Sonnenblick EH. Left ventricular diastolic suction as a mechanism of ventricular filling. Jpn Circ J. 46(1): pp 124-129;1982.

111. Robinson TF, Factor SM, Sonnenblick EH. The heart as a suction pump. Scientific American 254(6): pp 84-91;1986

112. Takahashi, K., Nii, M., Takigiku, K. et al. Development of suction force during early diastole from the left atrium to the left ventricle in infants, children, and adolescents. Heart Vessels 34, 296-306 (2019). https://doi.org/10.1007/ s00380-018-1239-9).

113. Little WC, Cheng CP. Oki T. Diastolic Dysfunction. Cardiol Rev. 1988;6(4):231-239.

114. Oki T. State of the art: 'diastology' research 1998. J Med Invest. 1998;45(1-4);9-25.

115. Marinelli R, Fürst B, van der Zee H, McGinn H, Marinelli W The heart is not a pump: a refutation of the pressure propulsion premise of heart function. Frontier Perspectives. Fall-Winter $1995,5(1) ; 15-24$.

116. Stonebridge PA, Brophy CM. Spiral flow in laminar arteries? Lancet. 338(8779): pp 1360$61 ; 1991$

117. Stonebridge PA, Hoskins PR, Allan PL, Belck JF. Spiral laminar flow in vivo. Clin Sci (Lond) 1996.91(1);17-21.

118. Kilner PJ, Yang GZ, Mohiaddin RH, Firmin $\mathrm{DN}$, Longmore DB. Helical and retrograde secondary flow patterns in the aortic arch studied by three-directional magnetic resonance velocity mapping. Circulation. 1993.88(5);2235-47.

119. Liu X, Sun A, Fan Y, Deng X. Physiological significance of helical flow in the arterial system and its potential clinical applications. Ann Biomed Engineer 43(1): pp 3-15; 2015 
120. Björn EW. Nordenström. Biologically Closed Electric Circuits: Clinical Experimental and Theoretical Evidence for an Additional Circulatory System. Nordic Medical Publications.1983

121. Siegel RE. Galen's System of Physiology and Medicine. 1968. publ. S. Karger.

122. Reaven GM. Banting Lecture 1988: Role of Insulin Resistance in Human Disease. Diabetes 37: pp 1595-1607; 1988.

123. Reaven GM. Role of Insulin Resistance in $\mathrm{Hu}$ man Disease (Syndrome X): an Expanded Definition. Annu Rev Med. 44: pp121-131;

124. Di Mauro R, Cantarella G, Bernardini R, Di Rosa M. The Biochemical and Pharmacological Properties of Ozone: The Smell of Protection in Acute and Chronic Diseases. 2019 Feb 1. Int J Mol Sci;20(3):634.

125. Sagai M, Bocci V. Mechanisms of Action Involved in Ozone Therapy: Is healing induced via a mild oxidative stress? Med Gas Res. 2011. Dec 20;1:29.

126. Elvis AM, Ekta JS. Ozone Therapy: A clinical review. J Nat Sci Biol Med. 2011;2(1):66-70.

127. Smith NL, Wilson AL, Gandhi J, Vatsia S, Khan SA. Ozone therapy: an overview of pharmacodynamics, current research, and clinical utility. Med Gas Res. 2017 Oct 17.7(3);212-219.

128. Oxidant-specific biomarkers of oxidative stress. Association with atherosclerosis and implication for antioxidant effects. Niki E Free Rad Biol Med 2018 May 20;120:425-440.

129. Pisoschi AM, Pop A. The role of antioxidants in the chemistry of oxidative stress: A review. 2015 Jun 5. Eur J Med Chem;97:55-74.

130. Kattoor AJ, Pothenini NVK, Palagiri D, Mehta JL. Oxidative Stress in Atherosclerosis. Curr Atheroscler Rep. 2017 Sep 18. 9(11);42.

131. Strohmaier H, Hinghofer-Szalkay H, Schaur RJ. Detection of 4-hydroxynonenal (HNE) as a physiological component in human plasma. J Lipid Mediat Cell Signal. 1995. 11:51-61.
132. Travagli V, Zanardi I, Silvietti A, Bocci V. A physicochemical investigation on the effects of ozone on blood. Int J Biol Macromol. 2007 Dec 1. 41(5);504-11.

133. Mendiratta S, Qu ZC, May JM. Erythrocyte ascorbate recycling: Antioxidant effects in blood. Free Rad Biol Med. 1998. 24: 789-797.

134. Mendiratta S, Qu ZC, May JM. Enzyme-dependent ascorbate recycling in human erythrocytes: Role of thioredoxin reductase. Free Rad Biol Med. 1998. 25;221-228.

135. Graves DB. The emerging role of reactive oxygen and nitrogen species in redox biology and some implications for plasma applications to medicine and biology. J Phys D Appl Phys. 2012. 45;263001.

136. Rice-Evans C, Miller NJ. Total antioxidant status in plasma and body fluids. Methods Enzymol 1994; 234:279-293.

137. Grau M, Lauten A, Hoeppener S, Goebel B et al Regulation of red blood cell deformability is independent of red blood cell-nitric oxide synthase under hypoxia. Clin Hemorheol Microcirc. 2016 Sep 12. 63(3);199-215.

138. Grau M, Kollikowski A, Bloch W. Remote ischemia preconditioning increases red blood cell deformability through red blood cell-nitric oxide synthase activation. Clin Hemorheol Microcirc. 2016 Sep 12.63(3):185-97.

139. Simmonds MJ, Detterich JA, Connes P. Nitric oxide, vasodilation and the red blood cell. Biorheology 2014. 51(2-3);121-34.

140. Rassaf T, Totzeck M, Hendgen-Cotta UB, Shiva S, Heusch G, Kelm M. Circulating nitrite contributes to cardioprotection by remote ischemic preconditioning. Circ Res. 2014 May 9;114(10):1601-10.

141. Tomschi F, Niemann D, Bloch W, Predel HG, Grau M. Ischemic Preconditioning enhances performance and erythrocyte deformability of responders. Int J Sports Med. 2018 Jul. 39(8);596-603. 
142. Gopalakrishnan M, Saurabh S. Is red blood cell a mediator of remote ischaemic preconditioning? Med Hypotheses. 2014 Dec. 83(6);816-8.

143. Schmidt H, Feelisch M. Red blood cell-derived nitric oxide bioactivity and hypoxic vasodilation. Circulation. 2019 Jun 4;139(23):26642667.

144. Cosby K, Partovi KS, Crawford JH, Patel RP et al. Nitrite reduction to nitric oxide by deoxyhemoglobin vasodilated the human circulation. Nat Med 2003 Dec. 9(12):1498-505.

145. Nagababu E, Ramasamy S, Abernethy DR, Rifkind JM. Active nitric oxide produced in the red cell under hypoxic conditions by deoxyhemoglobin-mediated nitrite reduction. J Biol Chem. 2003 Nov 21. 278(47);46349-56.

146. Dejam A, Hunter CJ, Pelletier MM, Hsu LJ, et al. Erythrocytes are major intravascular storage sites of nitrite in human blood. Blood. $2005 \mathrm{Jul}$ 15.106(2);734-9.

147. Ellsworth ML, Ellis CG, Goldman D, Stephenson $\mathrm{AH}$, et al. Erythrocytes: Oxygen sensors and modulators of vascular tone. Physiology (Bethesda) 2009 Apr.24;107-16.

148. Nicolay JP, Liebig G, Niemoeller OM, Koka S, et al. Inhibition of suicidal erythrocyte death by nitric oxide. Pflugers Arch. 2008 May;456(2):293305.

149. Choudhry H, Harris AL. Advances in hypoxia-inducible factor biology. Cell Metab. 2018 Feb 6;27(2):281-298.

150. Zhang X, Yu Y, Lei H, Cai Y, et al. The Nrf-2/ HO-1 Signaling Axis: A Ray of Hope in Cardiovascular Diseases. Cardiol Res Pract. 2020. Jan 30;2020:5695723.

151. Saha S, Buttari B, Panieri E, Profumo E, Saso L. An Overview of Nrf2 Signaling Pathway and Its Role in Inflammation. Molecules $2020 \mathrm{Nov}$ 23;25(22):5474.

152. Loboda A, Damulewicz M, Pyza E, et al. Role of Nrf2/HO-1 system in development, oxidative stress response and diseases: an evolutionarily conserved mechanism. Cell Mol Life Sci. 2016 Sep.73(17):3221-47.

153. Pecorelli A, Bocci V, Acquaviva A, Belmonte G, et al. Nrf2 activation is involved in ozonated human serum upregulation of $\mathrm{HO}-1$ in endothelial cells. Toxicol Appl Pharmacol. 2013.267;30-40.

154. Re L, Martinez-Sanchez G, Bordicchia M, et al. Is ozone pre-conditioning effect linked to Nrf2/ EpRE activation pathway in vivo? A preliminary result. Eur J Pharmacol. 2014. 742:158-162.

155. Mann GE, Niehueser-Saran J, Watson A, Gao L, et al. Sheng Li Xue Bao. Nrf2/ARE regulated antioxidant gene expression in endothelial and smooth muscle cells in oxidative stress: implications for atherosclerosis and preeclampsia. 2007 Apr;59(2):117-27.

156. Surh YJ, Kundu JK, Na HK. Nrf2 as a master redox switch in turning on the cellular signaling involved in the induction of cytoprotective genes by some chemopreventive phytochemicals. Planta Med. 2008 Oct. 74(13);1526-39.

157. Duckers HJ, Boehm M. True AL, et al. Heme oxygenase-1 protects against vascular constriction and proliferation. Nature Med. 2001.7:693698.

158. Bach FH. Heme oxygenase-1 as a protective gene. Wiener Klinische Wochenschrift. 2002.114:1-3.

159. Durante W. J Heme oxygenase- 1 in growth control and its clinical application to vascular disease. Cell Physiol. 2003.195;373-382.

160. Maines MD. The heme oxygenase system: past, present, and Future. Antiox and Redox Signaling. 2004. 6(5);797-801.

161. Takahashi T, Morita K, Akagi R, Sassa S. Heme oxygenase-1: a novel therapeutic target in oxidative tissue injuries. Curr Med Chem. 2004.11(12);1545-1561.

162. Soares MP. Heme oxygenase-1 (HO-1), a protective gene that prevents chronic graft dysfunction. Camara NOS, Free Rad Biol Med. 2005. 38(4);426-435. 
163. Yamashita K, Ilinger RO, McDaid J, et al. Heme oxygenase- 1 is essential for and promotes tolerance to transplanted organs. FASEB. 2006. 20(6);776-778.

164. Tamion F, Richard V, Lacoume Y, Thuillez C. Intestinal preconditioning prevents systemic inflammatory response in hemorrhagic shock. Role of HO-1. Am J Physiol Gastrointest Liver Physiol. 2002 Aug. 283(2);G408-14.

165. Bergeron M, Ferriero DM, Vreman HJ. et al. Hypoxia-ischemia, but not hypoxia alone, induces the expression of heme oxygenase-1 (HSP32) in newborn rat brain. J Cereb Blood Flow Metab. 1997 Jun. 17(6);647-58.

166. Wang Y, Shen J, Xiong X, Xu Y, et al. Remote ischemic preconditioning protects against liver ischemia-reperfusion injury via heme oxygenase-1-induced autophagy. PLoS One. 2014 Jun. 10;9(6):e98834.

167. Peng TC, Jan WC, Tsai PS, Huang CJ. Heme oxygenase-1 mediates the protective effects of ischemic preconditioning on mitigating lung injury induced by lower limb ischemia-reperfusion in rats. J Surg Res. 2011. May15;167(2):e245-53.

168. Choi AM, Alam J.Am J Respir Cell Mol Biol. Heme oxygenase-1: function, regulation, and implication of a novel stress-inducible protein in oxidant-induced lung injury. 1996 Jul.15(1);9-19.

169. Kelley N, Jeltema D, Duan Y, He Y The NLRP3 Inflammasome: An Overview of Mechanisms of Activation and Regulation. Int J Mol Sci. 2019 Jul 6. 20(13);3328.

170. Zhou R, Yazdi AS, Menu P, Tschopp J. Nature A role for mitochondria in NLRP3 inflammasome activation. 2011 Jan 13. 469(7329);221-5.

171. Jo EK, Kim JK, Shin DM, Sasakawa C. Molecular mechanisms regulating NLRP3 inflammasome activation. Cell Mol Immunol. 2016 Mar. 13(2);148-59.

172. Liu Q, Zhang D, Hu D, et al. The role of mitochondria in NLRP3 inflammasome activation. Mol Immunol. 2018 Nov. 103;115-124.
173. Sutterwala FS, Haasken S, Cassel SL. Mechanism of NLRP3 inflammasome activation. Ann N Y Acad Sci. 2014 Jun. 1319(1):82-95.

174. Yu G, Bai Z, Chen Z, Chen H, et al. The NLRP3 inflammasome is a potential target of ozone therapy aiming to ease chronic renal inflammation in chronic kidney disease. Int Immunopharmacol. 2017 Feb. 43;203-209.

175. Kucukgul A, Erdogan S, Gonenci R, Ozan G. Beneficial effects of nontoxic ozone on $\mathrm{H}(2)$ $\mathrm{O}(2)$-induced stress and inflammation. Biochem Cell Biol. 2016 Dec. 94(6);577-583.

176. Caliskan B, Guven A, Ozler M, Cayci T, et al. Ozone therapy prevents renal inflammation and fibrosis in a rat model of acute pyelonephritis. Scand J Clin Lab Invest. 2011 Oct. 71(6);473-80.

177. Jose P, Ramabhadran BK, Emmatty R, Paul TP. Assessment of the effect of ozonated water irrigation on gingival inflammation in patients undergoing fixed orthodontic treatment. J Indian Soc Periodontol 2017 Nov-Dec. 21(6);484-488.

178. Tartari APS, Moreira FF, Pereira MCDS, et al. Anti-inflammatory Effect of Ozone Therapy in an Experimental Model of Rheumatoid Arthritis. Inflammation. 2020 Jun. 43(3);985-993.

179. Wang Z, Han Q, Guo YL, Liu XH, Qiu T. Effect of ozone oxidative preconditioning on inflammation and oxidative stress injury in rat model of renal transplantation. Acta Cir Bras. 2018 Mar. 33(3);238-249.

180. Hernández A, Viñals M, Isidoro T, Vilás F. Potential Role of Oxygen-Ozone Therapy in Treatment of COVID-19 Pneumonia. Am J Case Rep. 2020 Aug 17. 21:e925849.

181. Wei A, Feng H, Jia XM, et al. Ozone therapy ameliorates inflammation and endometrial injury in rats with pelvic ilnflammatory disease. Biomed Pharmacother. 2018 Nov. 107;14181425.

182. Güçlü A, Erken HA, Erken G, Dodurga Y, et al. The effects of ozone therapy on caspase pathways, TNF-alpha, and HIF-1alpha in diabetic nephropathy. Int Urol Nephrol. 2016 Mar. 
48(3);441-50.

183. Aslaner A, Çakır T, Tekeli SÖ, Avcı S, et al. Medical ozone treatment ameliorates the acute distal colitis in rat. Acta Cir Bras 2016 Apr;31(4):25663.

184. Turer AT, Hill JA. Pathogenesis of myocardial ischemia-reperfusion injury and rationale for therapy. Am J Cardiol 2010 Aug 1;106(3):360-8.

185. Hausenloy DJ, Yellon DM J. Myocardial ischemia-reperfusion injury: a neglected therapeutic target. Clin Invest. 2013. 123(1);92-100.

186. Tanigawa K. Reperfusion injury in liver transplantation. Curr Opin Anesthesiol. 2000 Jun.13(3);349-54.

187. Francischetti I,, Moreno JB, Scholz M, Yoshida WB. Leukocytes and the inflammatory response in ischemia-reperfusion injury. Rev Bras Cir Cardiovasc. 2010 Oct-Dec. 25(4);575-84.

188. Zuidema MY, Zhang C. Ischemia/reperfusion injury: The role of immune cells. World J Cardiol 2010 Oct 26. 2(10);325-32.

189. den Hengst WA, Gielis JF, Lin JY, Van Schil PE, De Windt LJ, Moens AL. Lung ischemia-reperfusion injury: a molecular and clinical view on a complex pathophysiological process. Am J Physiol Heart Circ Physiol. 2010 Nov. 299(5);H1283-99.

190. Abu-Amara M, Yang SY, Tapuria N, Fuller B, Davidson B, Seifalian. A Liver ischemia/reperfusion injury: processes in inflammatory networks--a review. Liver Transplan. 2010. 16(9);1016-32.

191. Ambrosio G, Tritto I. Reperfusion injury: experimental evidence and clinical implications. Am Heart J 1999 Aug. 138(2 Pt 2);S69-75.

192. Jennings RB, Sommers HM, Smyth GA, Flack HA, Linn H. Myocardial necrosis induced by temporary occlusion of a coronary artery in the dog. Arch Pathol.1960 Jul. 70;68-78.

193. Staat P, Rioufol G, Piot C, Cottin Y, Cung TT, L'Huillier I, Aupetit JF, Bonnefoy E, Finet G, Andre-Fouet X, Ovize M. Postconditioning the human heart. Circulation. 2005. 112;21432148 .

194. Chen H, Xing B, Liu X, et al. Ozone oxidative preconditioning protects the rat kidney from reperfusion injury: the role of nitric oxide. J Surg Res. 2008. 149;287-295.

195. Orakdogen M, Uslu S, Emon ST, Somay H, Meric $\mathrm{ZC}$, Hakan T. The effect of ozone therapy on experimental vasospasm in the rat femoral artery. Turk Neurosurg. 2016. 26;860-865.

196. Cai H-A, Tao X, Zheng L-J, Huang L, et al. Ozone alleviates ischemia/reperfusion injury by inhibiting mitochondrion-mediated apoptosis pathway in SH-SY5Y cells. Cell Biol Int. 2020 Apr. 44(4);975-984.

197. Aslan MK, Boybeyi O, Senyücel MF, Ücler SA, et al. Protective effect of intraperitoneal ozone application in experimental ovarian ischemia/ reperfusion injury. J Pediatr Surg. 2012 Sep. 47(9);1730-4.

198. Jiang B, Su Y, Chen Q, et al. Protective Effects of Ozone Oxidative Postconditioning on Long-term Injury After Renal Ischemia/Reperfusion in Rat. Transplant Proc. Jan-Feb 2020. 52(1);365-372.

199. 199. Wang L, Chen Z, Weng X, et al. Combined Ischemic Postconditioning and Ozone Postconditioning Provides Synergistic Protection Against Renal Ischemia and Reperfusion Injury Through Inhibiting Pyroptosis. Urology 2019 Jan;123:296.e1-296.e8.

200. Wang L, Chen Z, Liu Y, et al. Ozone oxidative postconditioning inhibits oxidative stress and apoptosis in renal ischemia and reperfusion injury through inhibition of MAPK signaling pathway. Drug Des Devel Ther. 2018 May 21,12;1293-1301.

201. Gülmen KA, Kocyigit A, Kurtoglu T, et al. The effect of ozone treatment on remote organ myocardial injury in an aortic ischemia-reperfusion model. Turk Gogus Kalp Damar Cerrahisi Derg. 2018 Apr 30. 26(2);207-213.

202. Wang L, Chen Z, Liu Y, et al. Ozone oxidative 
preconditioning inhibits oxidative stress and apoptosis in renal ischemia and reperfusion injury through inhibition of MAPK signaling pathway. Drug Des Devel Ther. 2018 May 21. 12;1293-1301.

203. Wang Z, Zhang A, Meng W, Wang T, Li D, Liu Z, Liu $\mathrm{H}$. Ozone protects the rat lung from ischemia-reperfusion injury by attenuating NLRP3-mediated inflammation, enhancing Nrf2 antioxidant activity and inhibiting apoptosis. Eur J Pharmacol. 2018 Sep 15. 835;82-93.

204. Meng W, Xu Y, Li D, Zhu E, et al. Ozone protects rat heart against ischemia-reperfusion injury: A role for oxidative preconditioning in attenuating mitochondrial injury. Biomed Pharmacother. 2017 Apr. 88;1090-1097.

205. Onal O, Yetisir F, Sarer AE, Zeybek ND. Prophylactic ozone administration reduces intestinal mucosa injury induced by intestinal ischemia-reperfusion in the rat. Mediators Inflamm. 2015. 2015;792016.

206. Merin O, Attias E, Elstein D, Schwalb H, et al. Ozone administration reduces reperfusion injury in an isolated rat heart model. Card Surg 2007 Jul-Aug;22(4):339-42.

207. Kal A, Kal O, Akillioglu I, Celik E et al. The protective effect of prophylactic ozone administration against retinal ischemia-reperfusion injury. Cutan Ocul Toxicol. 2017. 36(1);39-47.

208. Oztosun M, Akgul EO, Cakir E, Cayci T, et al. The effects of medical ozone therapy on renal ischemia/reperfusion injury. Ren Fail. 2012. 34(7);921-5.

209. Aslan MK, Boybeyi Ö, Şenyücel MF, et al. Protective effect of intraperitoneal ozone application in experimental ovarian ischemia/reperfusion injury. Pediatr Surg. 2012 Sep. 47(9);1730-4.

210. Haj B, Sukhotnik I, Shaoul R, Pollak Y, et al. Effect of ozone on intestinal recovery following intestinal ischemia-reperfusion injury in a rat. Surg Int. 2014 Feb. 30(2);181-8.

211. Wang L, Chen H, Liu XH, Chen ZY et al. Ozone oxidative preconditioning inhibits renal fibrosis induced by ischemia and reperfusion injury in rats. Exp Ther Med. 2014 Dec. 8(6);1764-1768.

212. Ahmed LA, Salem HA, Mawsouf MN, et al. Cardioprotective effects of ozone oxidative preconditioning in an in vivo model of ischemia/ reperfusion injury in rats. Scand J Clin Lab Invest. 2012 Sep. 72(5);345-54.

213. Wang Z, Han Q, Guo YL, et al. Effect of ozone oxidative preconditioning on inflammation and oxidative stress injury in rat model of renal transplantation. Acta Cir Bras. 2018. 33(3);238249.

214. León Fernández OS, Ajamieh HH, Berlanga J, Menéndez S, et al. Ozone oxidative preconditioning is mediated by $\mathrm{A} 1$ adenosine receptors in a rat model of liver ischemia/ reperfusion. Transpl Int 2008 Jan;21(1):39-48.

215. Chen H, Xing B, Liu X, Zhan B, et al. Ozone oxidative preconditioning protects the rat kidney from reperfusion injury: the role of nitric oxide. J Surg Res. 2008 Oct. 149(2);287-95.

216. Wang L, Chen H, Liu XH, et al. The protective effect of ozone oxidative preconditioning against hypoxia/reoxygenation injury in rat kidney cells. Ren Fail. 2014. 36(9);1449-54.

217. Peralta C, Xaus C, Bartrons R, Leon OS, et al. Effect of ozone treatment on reactive oxygen species and adenosine production during hepatic ischemia-reperfusion. Free Radic Res. 2000 Nov. 33(5);595-605.

218. Ajamieh HH, Menéndez S, Martínez-Sánchez $\mathrm{G}$, Candelario-Jalil E, et al. Effects of ozone oxidative preconditioning on nitric oxide generation and cellular redox balance in a rat model of hepatic ischaemia-reperfusion. Liver Int. 2004 Feb. 24(1);55-62.

219. Filippo C, Marfella R, Capodanno P, et al. Acute oxygen-ozone administration to rats protects the heart from ischemia reperfusion infarct. Inflamm Res. 2008. 57(10);445-49.

220. Tusat M, Mentese A, Demir S, et al. Medical ozone therapy reduces oxidative stress and testicular damage in an experimental model of 
testicular torsion in rats. Int Braz J Urol. 2017 Nov-Dec. 43(6);1160-1166.

221. Foglieni C, Fulgenzi A, Belloni D, Sciorati C, et al. Ozonated autohemotherapy: protection of kidneys from ischemia in rats subjected to unilateral nephrectomy. Nephrol. 2011 Nov 14. $12 ; 61$.

222. Effects of ozone oxidative preconditioning on liver regeneration after partial hepatectomy in rats. Gultekin FA, Cakmak GK, Turkcu UO, et al. Invest Surg 2013;26(5):242-52.

223. Di Filippo C, Cervone C, Rossi C, di Ronza C, et al. Antiarrhythmic effect of acute oxygen-ozone administration to rats. Eur J Pharmacol. 2010 Mar 10. 629(1-3);89-95.

224. Stadlbauer TH, Eisele A, Heidt MC, et al. Preconditioning with ozone abrogates acute rejection and prolongs cardiac allograft survival in rats. Transplant Proc. 2008 May. 40(4):974-7.

225. Ajamieh H, Merino N, Candelario-Jalil E, et al. Similar protective effect of ischaemic and ozone oxidative preconditionings in liver ischaemia/ reperfusion injury. Pharmacol Res. 2002 Apr. 45(4);333-9.

226. Chen H, Xing B, Liu X, et al. Similarities between ozone oxidative preconditioning and ischemic preconditioning in renal ischemia/reperfusion injury. Arch Med Res. 2008;39(2):169-78.

227. Bouleti C, Mewton N, Germain S. The no-reflow phenomenon: State of the art. Arch Cardiovasc Dis. 2015 Dec;108(12): 661-74.

228. Prasad SB, See V, Brown P, McKay T, Narayan A, Kovoor P, Thomas L. Impact of duration of ischemia on left ventricular diastolic properties following reperfusion for acute myocardial infarction. Am J Cardiol 2011. Aug 1. 108(3):34854.

229. Prasad A, Gersh BJ, Mehran R, et al. Effect of Ischemia Duration and Door-to-Balloon Time on Myocardial Perfusion in ST-Segment Elevation Myocardial Infarction: An Analysis From HORIZONS-AMI Trial (Harmonizing Outcomes with Revascularization and Stents in Acute
Myocardial Infarction). J Am Coll Cardiol Cardiovasc Interv. 2015. Dec 28. 8(15);1966-1974.

230. Fernández-Jiménez R, Galán-Arriola C, Sánchez-González J, et al. Effect of Ischemia Duration and Protective Interventions on the Temporal Dynamics of Tissue Composition After Myocardial Infarction. Circ Res. 2017 Aug 4.121(4);439-450.

231. Ferdinandy P, Hausenloy DJ, Heusch G, Baxter GF, Schulz R. Interaction of risk factors, comorbidities, and comedications with ische$\mathrm{mia} /$ reperfusion injury and cardioprotection by preconditioning, postconditioning, and remote conditioning. Pharmacol Rev. 2014 Oct. 66(4);1142-74.

232. Pagliaro P, Penna C. Hypertension, hypertrophy, and reperfusion injury. J Cardiovasc Med 2017 Mar;18(3):131-135.

233. Lejay A, Fang F, John R, Van JA, Barr M, Thaveau F, Chakfe N, Geny B, Scholey JW. Ischemia reperfusion injury, ischemic conditioning and diabetes mellitus. J Mol Cell Cardiol. 2016. 91:11-22.

234. Davies SS, Traustadóttir T, Stock AA, Ye F, Shyr Y, Harman SM, Roberts LJ. Ischemia / reperfusion unveils impaired capacity of older adults to restrain oxidative insult. Free Rad Biol Med. 2009 Oct 1. 47(7);1014-8.

235. Albadawi H, Oklu R, Cormier NR, O'Keefe RM, Heaton JT, Kobler JB, Austen WG, Watkins MT. Hind limb ischemia-reperfusion injury in diet-induced obese mice. J Surg Res. 2014 Aug. 190(2);683-91.

236. Seal JB, Gewertz BL. Vascular dysfunction in ischemia-reperfusion injury. Ann Vasc Surg 2005 Jul;19(4):572-84.

237. The central role of renal microcirculatory dysfunction in the pathogenesis of acute kidney injury. Ince C. Nephron Clin Pract. 2014. 127(14):124-8.

238. Role of microcirculation in hepatic ischemia/ reperfusion injury. Menger MD, Richter S, Yamauchi J, Vollmar B. Hepatogastroenterology 
1999 Jun;46 Suppl 2:1452-7

239. Granger DN. Ischemia-reperfusion: mechanis$\mathrm{ms}$ of microvascular dysfunction and the influence of risk factors for cardiovascular disease. Microcirculation 1999 Sep;6(3):167-78.

240. Pemberton M, Anderson G, Barker J. In vivo microscopy of microcirculatory injury in skeletal muscle following ischemia/reperfusion. Microsurgery 1994.15(6);374-82.

241. Ganesh T, Zakher E, Estrada M, Cheng HM. Assessment of microvascular dysfunction in acute limb ischemia-reperfusion injury. J Magnet Res Imaging. 2018 Oct 9;1174-1185.

242. Menger MD, Pelikan S, Steiner D, Messmer K. Microvascular ischemia-reperfusion injury in striated muscle: significance of "reflow paradox". Am J Physiol. 1992 Dec. 263(6 Pt 2);H1901-6.

243. Vascular Pathology of Ischemia/Reperfusion Injury of Rat Small Intestine. Gordeeva AE, Sharapov MG, Tikhonova IV, Chemeris NK, Fesenko EE, Novoselov VI, Temnov AA. Cells Tissues Organs 2017;203(6):353-364

244. Menger MD, Messmer K. Microcirculation of skeletal muscle after ischemia and reperfusion. Wien Med Wochenschr. 1993. 143(7-8);148-58.

245. Vinten-Johansen J, Zhao ZQ, Nakamura M, Jordan JE, Ronson RS, Thourani VH, Guyton RA. Nitric oxide and the vascular endothelium in myocardial ischemia-reperfusion injury. Ann NY Acad Sci. 1999 Jun 30. 874;354-70.

246. Guan Z, Gobé G, Willgoss D, Endre ZH. Renal endothelial dysfunction and impaired autoregulation after ischemia-reperfusion injury result from excess nitric oxide. Am J Physiol Renal Physiol. 2006 Sep. 291(3);F619-28.

247. Wang WZ, Anderson G, Fleming JT, et al. Lack of nitric oxide contributes to vasospasm during ischemia/reperfusion injury. Plast Reconstr Surg. 1997 Apr. 99(4);1099-108.

248. Eppinger MJ, Ward PA, Jones ML, Bolling SF, Deeb GM. Disparate effects of nitric oxide on lung ischemia-reperfusion injury. Ann Thorac
Surg.1995 Nov;60(5):1169-75.

249. Guan Z, Gobé G, Willgoss D, Endre ZH. Renal endothelial dysfunction and impaired autoregulation after ischemia-reperfusion injury result from excess nitric oxide. Am J Physiol Renal Physiol 2006 Sep.291(3);F619-28.

250. Gürsoy-Ozdemir Y, Bolay H, Saribaş O, Dalkara T. Role of endothelial nitric oxide generation and peroxynitrite formation in reperfusion injury after focal cerebral ischemia. Stroke. 2000 Aug. 31(8);1974-80.

251. Köksoy C, Kuzu MA, Ergün H, et al. Intestinal ischemia and reperfusion impairs vasomotor functions of pulmonary vascular bed. Ann Surg 2000 Jan;231(1):105-11.

252. Pararajasingam R, Weight SC, Bell PR, Nicholson ML, Sayers RD. Pulmonary nitric oxide metabolism following infrarenal aortic cross-clamp-induced ischaemia-reperfusion injury. Eur J Vasc Endovasc Surg. 2000 Jan;19(1):47-51.

253. Lin HI, Chou SJ, Wang D, Feng NH, Feng E, Chen CF. Reperfusion liver injury induces down-regulation of eNOS and up-regulation of iNOS in lung tissues. Transplant Proc. 2006 Sep. 38(7);2203-6.

254. Horie Y, Ishii H. Liver dysfunction elicited by gut ischemia-reperfusion. Pathophysiol. 2001 Aug. 8(1);11-20.

255. Chen CF, Wang D, Lin HI, Leu FJ, Shen CY, Chou CC. Ischemia/reperfusion of the liver induces heart injury in rats. Transplant Proc 2007 May. 39(4):855-7.

256. Liu ZB, Yang WX, Fu XH, Zhao LF, Gao JL. Remote ischemic precondition prevents radial artery endothelial dysfunction induced by ischemia and reperfusion based on a cyclooxygenase-2-dependent mechanism. Int J Clin Exp Med. 2015 Nov 15. 8(11);20946-52.

257. Cutrn JC, Perrelli MG, Cavalieri B, Peralta C, Rosell Catafau J, Poli G. Microvascular dysfunction induced by reperfusion injury and protective effect of ischemic preconditioning. Free Rad Biol. 2002 Nov 1. 33(9);1200-8 
258. Dayton C, Yamaguchi T, Warren A, Korthuis RJ. Ischemic preconditioning prevents postischemic arteriolar, capillary, and postcapillary venular dysfunction: signaling pathways mediating the adaptive metamorphosis to a protected phenotype in preconditioned endothelium. Microcirculation. 2002 Apr;9(2):73-89.

259. Pasupathy S, Homer-Vanniasinkam S. Ischaemic preconditioning protects against ischae$\mathrm{mia} /$ reperfusion injury: emerging concepts. Eur J Vasc Endovasc Surg 2005 Feb;29(2):106-15.

260. Guan Z, Gobé G, Willgoss D, Endre ZH. Renal endothelial dysfunction and impaired autoregulation after ischemia-reperfusion injury result from excess nitric oxide. Am J Physiol Renal Physiol. 2006 Sep;291(3):F619-28

261. Hotter G, Closa D, Prados M, Fernández-Cruz $\mathrm{L}$, et al. Intestinal preconditioning is mediated by a transient increase in nitric oxide. Biochem Biophys Res Commun. 1996 May 6. 222(1);2732.

262. Meldrum DR, Mitchell MB, Banerjee A, Harken AH. Cardiac preconditioning. Induction of endogenous tolerance to ischemia-reperfusion injury. Arch Surg. 1993 Nov. 128(11);1208-11.

263. Richard V, Kaeffer N, Tron C, Thuillez C. Ischemic preconditioning protects against coronary endothelial dysfunction induced by ischemia and reperfusion. Circulation 1994 Mar. 89(3);1254-61.

264. Pagliaro P, Chiribiri A, Mancardi D, Rastaldo R, Gattullo D, Losano G. Coronary endothelial dysfunction after ischemia and reperfusion and its prevention by ischemic preconditioning. Ital Heart J. 2003 Jun. 4(6);383-94.

265. Kaplan LJ, Bellows CF, Blum H, Mitchell M, Whitman GJ. Ischemic preconditioning preserves end-ischemic ATP, enhancing functional recovery and coronary flow during reperfusion. J Surg Res. 1994 Jul. 57(1);179-84.

266. Duan YF, An Y, Zhu F, Jiang Y. Remote ischemic preconditioning protects liver ischemia-reperfusion injury by regulating eNOS-NO pathway and liver microRNA expressions in fatty liver rats. Hepatobiliary Pancreat Dis Int. 2017 Aug 15.16(4);387-394.

267. Rowen RJ. Ozone and oxidation therapies as a solution to the emerging crisis in infectious disease management: a review of current knowledge and experience. Med Gas Res. 2019(4); 232-237.

268. Izadi M, Cegolon L, Javanbakht M, Sarafzadeh A et al. Ozone therapy for the treatment of COVID-19 pneumonia: A scoping review. Int Immunopharmacol 2021.Mar;92:107307.

269. A plausible "penny" costing effective treatment for corona virus- ozone therapy. Rowen RJ, Robins H J Infect Dis Epidemiol. 2020. 13(6):

270. Zheng Z, Dong M, Hu K. A preliminary evaluation on the efficacy of ozone therapy in the treatment of COVID-19. J Med Virol. 2020 Nov;92(11):2348-2350. doi: 10.1002/jmv.26040. Epub 2020 Jul 11. PMID: 32437014; PMCID: PMC7280732.

271. Shah M, Captain J, Vaidya V, et al. Safety and efficacy of ozone therapy in mild to moderate COVID-19 patients: A phase 1/11 randomized control trial (SEOT study). International Immunopharmacology 2021.91:107301

272. Hernández A, Viñals M, Pablos A, Vilás F, Papadakos PJ, Wijeysundera DN, Bergese SD, Vives M. Ozone therapy for patients with COVID-19 pneumonia: Preliminary report of a prospective case-control study. Int Immunopharmacol. 2021 Jan;90:107261. doi: 10.1016/j. intimp.2020.107261. Epub 2020 Dec 5. PMID: 33310665; PMCID: PMC7833586.

273. Franzini M, L. Valdenassi, G. Ricevuti, S. Chirumbolo, M. Depfenhart, D. Bertossi, U. Tirelli, Oxygen-ozone $(\mathrm{O}(2)-\mathrm{O}(3))$ immunoceutical therapy for patients with COVID-19. Preliminary evidence reported, Int. Immunopharmacol. 88 (2020), 106879, https://doi.org/10.1016/j.intimp.2020.106879.

274. G. Martínez-Sanchez, A. Schwartz, V. Di Donna, Potential Cytoprotective Activity of Ozone Therapy in SARS-CoV-2/COVID-19, Antioxidants (Basel, Switzerland) 9 (2020) 389, https:// 
doi.org/10.3390/antiox9050389. [15] A.

275. Gavazza A, Marchegiani A, Rossi G, Franzini M, Spaterna A, Mangiaterra S, Cerquetella M. Ozone Therapy as a Possible Option in COVID-19 Management. Front Public Health. 2020 Aug 25;8:417. doi: 10.3389/fpubh.2020.00417. PMID: 32984235; PMCID: PMC7477102.

276. Martınez-Sanchez G, Al-Dalain SM, Menendez $S, \operatorname{Re} L$ et al. Therapeutic efficacy of ozone in patients with diabetic foot. Eur J Pharmacol. 2005; 523:151-161.

277. M.E. Fernandez-Cuadros, ' M.J. Albaladejo-Florín, D. Pena-Lora, S. Alava-Rabasa, O. S. $\mathrm{P}^{\prime}$ erez-Moro, Ozone (O3) and SARS-CoV-2: Physiological Bases and Their Therapeutic Possibilities According to COVID-19 Evolutionary Stage, SN Compr, Clin. Med. (2020) 1-9, https://doi.org/10.1007/s42399-020-00328-7.

278. U.T.L. Valdenassi, M. Franzini, G. Ricevuti, L. Rinaldi, A.C. Galoforo, Potential mechanisms by which the oxygen-ozone (O2-O3) therapy could contribute to the treatment against the coronavirus COVID-19, Eur Rev Med Pharmacol Sci. 24 (2020) 4059-4061.]

279. Thorp JA, Hollonbeck SA, Viglione DD, Green PC, Hodge JR, et al. (2020) Novel therapy for COVID-19 does intravenous ozonated-saline affect blood and tissue oxygenation? J Gynecol Res Obstet 6(2): 046-050. DOI: https://dx.doi. org/10.17352/jgro.000085.

280. Cattel F, Giordano S, Bertiond C, Lupia S, et al. Ozone therapy in COVID-19: A narrative review, Virus Res. 291 (2021), 198207, https://doi. org/10.1016/j.viruses.2020.198207.

281. Hernández A, Viñals M, Pablos A et al Ozone therapy for patients with COVID-19 pneumonia: Preliminary report of a prospective case-control study. Int Immunopharmacol 2021 Jan;90:107261.

282. Chang JD, Lu HS, Chang YF et al Ameliorative effect of ozone on cytokine production in mice injected with human rheumatoid arthritis synovial fibroblast cells. Rheumatol Int 2005 Dec;26(2):142-51.
283. Chen $\mathrm{H}, \mathrm{Yu} \mathrm{B}, \mathrm{Lu} \mathrm{C}$ et al The effect of intra-articular injection of different concentrations of ozone on the level of TNF-alpha, TNF-R1, and TNF-R2 in rats with rheumatoid arthritis. Rheumatol Int. 2013 May;33(5):1223-7.

284. Tartari APS, Moreira FF, Pereira MCDS et al Anti-inflammatory Effect of Ozone Therapy in an Experimental Model of Rheumatoid Arthritis. Inflammation. 2020 Jun;43(3):985-993.

285. Zeng J, Lei L, Zeng Q et al Ozone Therapy Attenuates NF-kappaB-Mediated Local Inflammatory Response and Activation of Th17 Cells in Treatment for Psoriasis. Int J Biol Sci. 2020 Apr 6;16(11):1833-1845.

286. Gao L, Dou J, Zhang B et al Ozone therapy promotes the differentiation of basal keratinocytes via increasing Tp63-mediated transcription of KRT10 to improve psoriasis. J Cell Mol Med. 2020 Apr;24(8):4819-4829.

287. Rowen RJ. Remission of aggressive autoimmune disease (dermatomyositis) with removal of infective jaw pathology and ozone therapy: review and case report. Autoimmunity Highlights (2018) 9:7 https://doi.org/10.1007/s13317-0180107-z.

288. Zeng J, Lei L, Zeng Q, et al. Ozone Therapy Attenuates NF- $\kappa \mathrm{B}$-Mediated Local Inflammatory Response and Activation of Th17 Cells in Treatment for Psoriasis. Int J Biol Sci. 2020 Apr. 16(11);1833-1845.

289. Tartari APS, Moreira FF, Pereira MCDS, Carraro E, et al. Anti-inflammatory Effect of Ozone Therapy in an Experimental Model of Rheumatoid Arthritis. Inflammation 2020 Jun. 43(3);985-993.

290. OAnWei, HaoFeng, Xiao-MinJia, HuaTang, Yang-YingLiao, Bi-RongLi. Ozone therapy ameliorates inflammation and endometrial injury in rats with pelvic inflammatory disease. Biomedicine \& Pharmacotherapy Volume 107, November 2018, Pages 1418-1425.

291. León Fernández OS, Viebahn-Haensler R, Cabreja GL, Espinosa IS, et al. Medical ozone increases methotrexate clinical response and im- 
proves cellular redox balance in patients with rheumatoid arthritis. Eur J Pharmacol 2016 Oct 15;789:313-318.

292. Hana X, Molinarib F, Rossatib S. Assesment of Ozone Autohemotherapy on Patients with Multiple Sclerosis by Time-frequency Analysis of Near-infrared Spectroscopy Signals. Journal of Bioelectromagnetism www.ijbem.org Vol. 18, No. 1, pp. 32 - 37, 2016 Wuhan University of Technology, Wuhan, P.R.China.

293. Zanardi I, Borrelli E, Valacchi G, Travagli V, Bocci V. Ozone: A Multifaceted Molecule with Unexpected Therapeutic Activity. Curr Med Chem. 2016;23(4):304-14. doi: 10.2174/092986 7323666151221150420. PMID: 26687830.

294. Dadashpour M, Yousefi M, Ahmadi M. Changes in Th17 cells frequency and function after ozone therapy used to treat multiple sclerosis patients. Mult Scler Relat Disord. 2020 Nov;46:102466. doi: 10.1016/j.msard.2020.102466. Epub 2020 Aug 24. PMID: 32862036.

295. Bocci V, Zanardia I, Valacchi G, Borrelli E, Travagli V. Validity of Oxygen-Ozone Therapy as Integrated Medication Form in Chronic Inflammatory Diseases. Cardiovasc Hematol Disord Drug Targets. 2015;15(2):127-38. doi: 10.2174/1871529x1502151209114642. PMID: 26126818 .

296. Bazzichi L, Giacomelli C, Consensi A, Giorgi V, Batticciotto A, Di Franco M, Sarzi-Puttini P. One year in review 2020: fibromyalgia. Clin Exp Rheumatol. 2020 Jan-Feb;38 Suppl 123(1):3-8. Epub 2020 Feb 21. PMID: 32116216.

297. Ozone therapy in 65 patients with fibromyalgia: an effective therapy. Tirelli U, Cirrito C, Pavanello $M$ et al Eur Rev Med Pharmacol Sci 2019; 23:1786-1788.

298. Autohemotherapy with ozone as a possible effective treatment for Fibromyalgia. Moreno-Fernandez A, Macias-Garcia L, Valverde-Moreno R et al. Acta Reumatol Port 2019; 44: 244-249.

299. Moreno-Fernández A, Macías-García L, Valverde-Moreno R, Ortiz T, Fernández-Rodríguez A,
Moliní-Estrada A, DeMiguel M. Autohemotherapy with ozone as a possible effective treatment for Fibromyalgia. Acta Reumatol Port. 2019. 44;244-249.

300. Hidalgo-Tallón J, Menéndez-Cepero S, Vilchez JS, Rodríguez-López CM, Calandre EP. Ozone therapy as add-on treatment in fibromyalgia management by rectal insufflation: An open-label pilot study. J. Altern. Complement. Med. $2013,19,238-242$.

301. Tirelli U, Cirrito C, Pavanello M, Piasentin C, Lleshi A, Taibi R. Ozone therapy in 65 patients with fibromyalgia: An effective therapy. Eur Rev Med Pharmacol Sci. 2019. 23;1786-1788.

302. Knowles TP, Vendruscolo M, Dobson CM. The amyloid state and its association with protein misfolding diseases. Nat Rev Mol Cell Biol. 2014 Jun;15(6):384-96. doi: 10.1038/ nrm3810. Erratum in: Nat Rev Mol Cell Biol. 2014 Jul;15(7):496. PMID: 24854788. 10.1016/j. ejphar.2017.06.017. Epub 2017 Jun 13. PMID: 28623000 .

303. Lin SY, Ma J, An JX, Qian XY, Wang Y, Cope DK, Williams JP. Ozone Inhibits APP/A $\beta$ Production and Improves Cognition in an APP/ PS1 Transgenic Mouse Model. Neuroscience. 2019 Oct 15;418:110-121. doi: 10.1016/j. neuroscience.2019.07.027. Epub 2019 Jul 23. PMID: 31349006.

304. Cassellati C, Galoforo AC, Bonvicini C, Esposito C, Ricevuti G. Ozone: a natural bioactive molecule with antioxidant property as potential new strategy in aging and in neurodegenerative disorders. Ageing Res Rev. 2020 Nov;63:101138. doi: 10.1016/j.arr.2020.101138. Epub 2020 Aug 15. PMID: 32810649; PMCID: PMC7428719.

305. Sagai M, Bocci V. Mechanisms of Action Involved in Ozone Therapy: Is healing induced via a mild oxidative stress? Med Gas Res. 2011 Dec 20;1:29. doi: 10.1186/2045-9912-1-29. PMID: 22185664; PMCID: PMC3298518.

306. Jiang B, Su Y, Chen Q, Dong L, Zhou W, Li H, Wang Y. Protective Effects of Ozone Oxidative Postconditioning on Long-term Injury After 
Renal Ischemia/Reperfusion in Rat. Transplant Proc. 2020 Jan-Feb;52(1):365-372.

307. Wang L, Chen Z, Liu Y, Du Y, Liu X. Ozone oxidative postconditioning inhibits oxidative stress and apoptosis in renal ischemia and reperfusion injury through inhibition of MAPK signaling pathway. Drug Des Devel Ther. 2018 May 21;12:1293-1301. doi: 10.2147/DDDT.S164927. PMID: 29861623; PMCID: PMC5968808.

308. Chen Z, Liu X, Yu G, Chen H, Wang L, Wang $\mathrm{Z}$, Qiu T, Weng X. Ozone therapy ameliorates tubulointerstitial inflammation by regulating TLR4 in adenine-induced CKD rats. Ren Fail. 2016 Jun;38(5):822-30. doi: 10.3109/0886022X.2016.1143757. Epub 2016 Feb 24. PMID: 26907800.

309. Güçlü A, Erken HA, Erken G, et al. The effects of ozone therapy on caspase pathways, TNF- $\alpha$, and HIF-1 $\alpha$ in diabetic nephropathy. Int Urol Nephrol. 2016 Mar;48(3):441-50. doi: 10.1007/ s11255-015-1169-8. Epub 2015 Nov 27. PMID: 26614261.

310. Uğuz S, Demirer Z, Uysal B, et al. Medical ozone therapy reduces shock wave therapy-induced renal injury. Ren Fail. 2016 Jul;38(6):974-81. doi: 10.3109/0886022X.2016. 1172941. Epub 2016 Apr 20. PMID: 27099130.

311. Kurtoglu T, Durmaz S, Akgullu C, et al. Ozone preconditioning attenuates contrast-induced nephropathy in rats. J Surg Res. 2015 May 15;195(2):604-11.doi: 10.1016/j.jss.2015.01.041. Epub 2015 Jan 29. PMID: 25770741.

312. Targeting and inflammation in chronic kidney disease. Ruiz S, Pergola PE, Zager RA, Vaziri ND Kidney Int. 2013. 83;1029-1041.

313. Ucar F, Taslipinar MY, Alp BF, et al. The effects of $\mathrm{N}$-acetylcysteine and ozone therapy on oxidative stress and inflammation in acetaminophen-induced nephrotoxicity model. Ren Fail. 2013;35(5):640-7. doi: 10.3109/0886022X.2013.780530. Epub 2013 Apr 8. PMID: 23560513.

314. Fernández Iglesias A, González Núñez L, Calunga Fernández JL, et al. Ozone postcondi- tioning in renal ischaemia-reperfusion model. Functional and morphological evidences. Nefrologia. 2011. 31(4);464-70.

315. Gu XB, Yang XJ, Zhu HY, et al. Effect of medical ozone therapy on renal blood flow and renal function of patients with chronic severe hepatitis. Chin Med J (Engl). 2010 Sep;123(18):25103. PMID: 21034619

316. Demirbag S, Uysal B, Guven A, et al. Effects of medical ozone therapy on acetaminophen-induced nephrotoxicity in rats. Ren Fail. 2010 May. 32(4):493-7. doi: 10.3109/08860221003646352. PMID: 20446790

317. Calunga JL, Trujillo Y, Menéndez S, et al. Ozone oxidative post-conditioning in acute renal failure. J Pharm Pharmacol. 2009 Feb;61(2):221-7. doi: 10.1211/jpp/61.02.0012. PMID: 19178770. English, Spanish. doi: 10.3265/Nefrologia. pre2011.May.10873. PMID: 21738249.

318. Biedunkiewicz B, Tylicki L, Rachon D, et al. Natural killer cell activity unaffected by ozonated autohemotherapy in patients with end-stage renal disease on maintenance renal replacement therapy. Int J Artif Organs. 2004 Sep;27(9):76671. doi: 10.1177/039139880402700906. PMID: 15521216. doi: 10.1016/j.transproceed.2019.10.004. Epub 2019 Dec 30. PMID: 31898937.

319. Gonzalez R, Borrego A, Zamora Z, et al. Reversion by ozone treatment of acute nephrotoxicity induced by cisplatin in rats. Mediators Inflamm. 2004.13;307-312.

320. Improvement of renal oxidative stress markers after ozone administration in diabetic nephropathy in rats. Morsy MD, Hassan WN, Zalat SI. Diabetol Metab Synd. 2010; 2: 29-35.

321. Sato H, Wananabe Y, Miyata H. Virucidal effect of ozone treatment of laboratory animal viruses. Jikken Dobutsu. 1990 Apr;39(2):223-9. doi: 10.1538/expanim1978.39.2_223. PMID: 2163330 .

322. Brié A, Boudaud N, Mssihid A, Loutreul J, Bertrand I, Gantzer C. Inactivation of murine norovirus and hepatitis A virus on fresh raspberries 
by gaseous ozone treatment. Food Microbiol. 2018 Apr;70:1-6. doi: 10.1016/j.fm.2017.08.010. Epub 2017 Aug 19. PMID: 29173615.

323. Zaky S, Kamel SE, Hassan MS, Sallam NA, Shahata MA, Helal SR, Mahmoud H. Preliminary results of ozone therapy as a possible treatment for patients with chronic hepatitis C. J Altern Complement Med. 2011 Mar;17(3):259-63. doi: 10.1089/acm.2010.0016. PMID: 21417811.

324. Ozone on Hepatobiliary function 324. Vaughn JM, Chen YS, Novotny JF, Strout D. Effects of ozone treatment on the infectivity of hepatitis A virus. Can J Microbiol. 1990 Aug;36(8):557-60. doi: 10.1139/m90-097. PMID: 2173968.

325. Chernyshev AL, Filimonov RM, Karasev AV, Neronov VA, Maksimov VA. [Combined treatment including ozonotherapy of patients with viral hepatitis ]. Vopr Kurortol Fizioter Lech Fiz Kult. 2008 May-Jun;(3):19-22. Russian. PMID: 18655281.

326. Jiao XJ, Peng X. [Clinilal study of medical ozone therapy in chronic hepatitis B of 20 patients]. Zhonghua Shi Yan He Lin Chuang Bing Du Xue Za Zhi. 2008 Dec;22(6):484-5. Chinese. PMID: 19544653.

327. Zaky S, Fouad EA, Kotb HI. The effect of rectal ozone on the portal vein oxygenation and pharmacokinetics of propranolol in liver cirrhosis (a preliminary human study). Br J Clin Pharmacol. 2011 Mar;71(3):411-5. doi: 10.1111/j.1365-2125.2010.03851.x. PMID: 21284700; PMCID: PMC3045550.

328. Kocaman H, Erginel B, Onder SY, Soysal FG, Keskin E, Celik A, Salman T. The Role of Ozone Therapy in Hepatic Fibrosis due to Biliary Tract Obstruction. Eur J Pediatr Surg. 2016 Feb;26(1):133-7. doi: 10.1055/s-0035-1571187. Epub 2016 Jan 5. PMID: 26731317.

329. Oxygen/ozone protects the heart from acute myocardial infarction through local increase of eNOS activity and endothelial progenitor cells recruitment. Di Filippo C, Luongo M, Marfella R, Ferraraccio F et al Naunyn Schmiedebergs Arch Pharmacol 2010 Sep;382(3):287-91.
330. Buyuklu, M., Kandemir, F.M., Set, T. et al. Beneficial Effects of Ozone Therapy on Oxidative Stress, Cardiac Functions and Clinical Findings in Patients with Heart Failure Reduced Ejection Fraction. Cardiovasc Toxicol 17, 426-433 (2017). https://doi.org/10.1007/s12012-0179400-8.

331. Zanardi I, Borrelli E, Valacchi G, Travagli V, Bocci V. Ozone: A Multifaceted Molecule with Unexpected Therapeutic Activity. Curr Med Chem. 2016;23(4):304-14. doi: 10.2174/092986 7323666151221150420. PMID: 26687830.

332. Weigman $\mathrm{CH}$, Michaeloudes $\mathrm{C}$, Haji $\mathrm{G}$ et al Oxidative stress-induced mitochondrial dysfunction drives inflammation and airway smooth muscle remodeling in patients with chronic obstructive pulmonary disease. J Allergy Clin Immunol 2015 Sep;136(3):769-80.

333. Kushmakov R, Gandhi J, Seyam O, Jiang W. Ozone therapy for diabetic foot. Med Gas Res 2018 Sep 25;8(3):111-115.

334. Wen Q, Chen Q. An Overview of Ozone Therapy for Treating Foot Ulcers in Patients With Diabetes. Am J Med Sci 2020 Aug;360(2):112119.

335. Zhang J, Guan M, Xie C, Luo X et al. Increased growth factors play a role in wound healing promoted by noninvasive oxygen-ozone therapy in diabetic patients with foot ulcers. Oxid Med Cell Longev 2014;2014:273475.

336. Wainstein J, Feldbrin Z, Boaz M, Harman-Boehm I. Efficacy of ozone-oxygen therapy for the treatment of diabetic foot ulcers. Diabetes Technol Ther 2011 Dec.13(12):1255-60.

337. Bocci V, Zanardi I, Huijberts MSP, Travagli V. Diabetes and chronic oxidative stress. A perspective based on the possible usefulness of ozone therapy. Diabetes Metab Syndr Jan-Mar 2011;5(1):45-9

338. Lim Y, Lee H, Woodby B, Valacchi G. Ozonated Oils and Cutaneous Wound Healing. Curr Pharm Des 2019;25(20):2264-2278

339. Martínez-Sánchez G, Saied M, Menendez S, 
et al. Therapeutic efficacy of ozone in patients with diabetic foot. Euro J Pharm 2005:523(13):151-161.

340. Orakdogen M, Uslu S, Emon ST, Somay H, Meric $\mathrm{ZC}$, HakanT. The effect of ozone therapy on experimental vasospasm in the rat femoral artery. Turk Neurosurg. 2016. 26;860-865.

341. Hassanien M, Rashad S, Mohamed N, Elawamy A. Non-invasive Oxygen-Ozone therapy in treating digital ulcers of patients with systemic sclerosis. Acta Reumatol Port 2018 Jul-Sep;43(3):210-216.

342. Kulikov AG, Turova EA, Shcherbina TM, Kisileva OM. [Efficacy of different methods of ozone therapy in vascular complications of diabetes mellitus.] Vopr Kurortol Fizioter Lech Fiz Kult. Sep-Oct 2002;(5):17-20

343. Xie TY, Yan W, Lou J, Chen XY. Effect of ozone on vascular endothelial growth factor (VEGF) and related inflammatory cytokines in rats with diabetic retinopathy. Genet Mol Res. 2016 May 13;15(2). doi: 10.4238/gmr.15027558. PMID: 27323014 .

344. Fitzpatrick E, Holland OJ, Vanderlelie JJ. Ozone therapy for the treatment of chronic wounds: A systematic review. Int Wound J. 2018. 15;633644.

345. Travagli V, Zanardi I, Valacchi G, Bocci V. Ozone and ozonated oils in skin diseases: a review., Mediators. Inflamm 2010. (2010 Article ID 610418, EPUB 2010) July 4, Review.

346. Taqwim Hidayat A, Thohar Arifin M, Nur M. Ozonated Aloe vera Oil Effective Increased the Number of Fibroblasts and Collagen Thickening in the Healing Response of Full-Thickness Skin Defects. Int J Inflam 2021 Feb; 2021.

347. Valacchi G, Lim Y, Belmonte G, Miracco C, et al. Ozonated sesame oil enhances cutaneous wound healing in SKH1 mice. Wound Repair Regen. 2011 Jan-Feb. 19(1);107-15.

348. Kim HS, Noh SU, Han YW, Kim KM et al. Therapeutic effects of topical application of ozone on acute cutaneous wound healing. J Korean
Med Sci 2009; 24: 368-374.

349. Lopes de Jesus CC, Dos Santos FC, de Jesus $\mathrm{LMOB}$ et al. Comparison between intra-articular ozone and placebo in the treatment of knee osteoarthritis: A randomized, double-blinded, placebo-controlled study. PLoS ONE 2017; 12; e0179185

350. Costa T, Linhares D, Ribeiro da Silva M, Nuno Neves N. Acta Reumatol Port. Jul-Sep 2018;43(3):172-181. Ozone therapy for low back pain. A systematic review

351. Fuccio C, Luongo C, Capodanno P, et al. A single subcutaneous injection of ozone prevents allodynia and decreases the over-expression of pro-inflammatory caspases in the orbito-frontal cortex of neuropathic mice. Eur J Pharmacol. 2008;603:42-49.

352. Seyam O, Smith NL, Reid I, Gandhi J, et al. Clinical utility of ozone therapy for musculoskeletal disorders. Med Gas Res 2018(8):103-110.

353. Ozone therapy as a treatment for low back pain secondary to herniated disc: A systematic review and meta-analysis of randomized controlled trials. Magalhaes, FN.; Dotta, L.; Sasse, A.; Teixera, M.J.; Fonoff, E.T. Pain Physician 2012, 15, E115-E129.

354. Rowen RJ, Robins, H. Ozone Therapy for Complex Regional Pain Syndrome: Review and Case Report. Curr Pain Headache Rep 23, 41 (2019). https://doi.org/10.1007/s11916-019-0776-y

355. de Sire A, Agostini F, Lippi L, Mangone M, Marchese S, Cisari C, Bernetti A, Invernizzi M. Oxygen-Ozone Therapy in the Rehabilitation Field: State of the Art on Mechanisms of Action, Safety and Effectiveness in Patients with Musculoskeletal Disorders. Biomolecules. 2021 Feb 26. 11(3);356.

356. Paoloni M, Di Sante L, Cacchio, A, Apuzzo D, Marotta S, Razzano M, Franzini M, Santilli, $\mathrm{V}$. Intramuscular oxygen-ozone therapy in the treatment of acute back pain with lumbar disc herniation: A multicenter, randomized, double-blind, clinical trial of active and simulated lumbar paravertebral injection. Spine. 
357. Ulusoy GR, Bilge A, Öztürk Ö. Comparison of corticosteroid injection and ozone injection for relief of pain in chronic lateral epicondylitis. Acta Orthop. Belg. 2019. 85;317-324.

358. Babaei-Ghazani, A.; Fadavi, H.R.; Eftekharsadat, B.; Ebadi, S.; Ahadi, T.; Ghazaei, F.; Khabbaz, M.S. A randomized control trial of comparing ultrasound-guided ozone $(\mathrm{O} 2-\mathrm{O} 3)$ vs. corticosteroid injection in patients with shoulder impingement. Am. J. Phys. Med. Rehabil. 2019, 98, 1018-1025.

359. Apuzzo D, Giotti C, Pasqualetti P, Ferrazza P, Soldati P, Zucco GM. An observational retrospective/horizontal study to compare oxygen-ozone therapy and/or global postural re-education in complicated chronic low back pain. Funct. Neurol. 2014, 29, 31-39.

360. Arias-Vázquez, P.I.; Tovilla-Zárate, C.A.; Hernández-Díaz, Y.; González-Castro, T.B.; Juárez-Rojop, I.E.; López-Narváez, M.L.; Bermudez-Ocaña, D.Y;; Barjau-Madrígal, H.A.; Legorreta-Ramírez, G. Short-Term Therapeutic Effects of Ozone in the Management of Pain in Knee Osteoarthritis: A Meta-Analysis. PM R 2019, 11, 879-887.

361. Noori-Zadeh, A.; Bakhtiyari, S.; Khooz, R.; Haghani, K.; Darabi, S. Intra-articular ozone therapy efficiently attenuates pain in knee osteoarthritic subjects: A systematic review and meta-analysis. Complement. Ther. Med. 2019, $42,240-247$

362. Barbosa LT, Rodrigues CF, Andrade RR, Barbosa FT. The effectiveness of percutaneous injections of ozonotherapy in low back pain. Rev. Assoc. Med. Bras. 2020, 66, 1146-1151.

363. Niu, T.; Lv, C.; Yi, G.; Tang, H.; Gong, C.; Niu, S. Therapeutic Effect of Medical Ozone on Lumbar Disc Herniation. Med. Sci. Monit. 2018, 24, 1962-1969.

364. Bonetti M, Fontana A, Cotticelli B, Volta GD, Guindani M. Leonardi M. Intraforaminal O2 -O3 versus periradicular steroidal infiltrations in lower back pain: Randomized controlled stu-
365. Muto M, Ambrosanio G, Guarnieri G, Capobianco E, Piccolo G, Annunziata G, Rotondo A. Low back pain and sciatica: Treatment with intradiscal-intraforaminal O2-O3 injection. Our experience. Radiol. Med. 2008, 113, 695-706.

366. Zhang Y, Ma Y, Jiang J, Ding, Wang J. Treatment of the lumbar disc herniation with intradiscal and intraforaminal injection of oxygen-ozone. J. Back Musculoskelet. Rehabil. 2013. 26;317-322.

367. Gallucci M, Limbucci N, Zugaro L, Barile A, Stavroulis E, Ricci A, Galzio R, Masciocchi C. Sciatica: Treatment with intradiscal and intraforaminal injections of steroid and oxygen-ozone versus steroid only. Radiology 2007, 242, 907913.

368. Perri M, Marsecano C, Varrassi M, Giordano AV, Splendiani A. di Cesare E, Masciocchi $\mathrm{C}$, Gallucci M. Indications and efficacy of $\mathrm{O} 2$ -O3 intradiscal versus steroid intraforaminal injection in different types of disco vertebral pathologies: A prospective randomized double-blind trial with 517 patients. Radiol Med. 2016. 121;463-471.

369. US Food \& Drug Administration; April 1, 2020: Code of Federal Regulations Title 21. https://www.accessdata.fda.gov/scripts/cdrh/ cfdocs/cfcfr/CFRSearch.cfm?FR=801.415

370. Federal Trade Commission April 23, 2020. Warning Letter. FTC Sends 21 Letters Warning Marketers to Stop Making Unsupported Claims That Their Products and Therapies Can Effectively Treat Coronavirus https://www.ftc.gov/news-events/press-releases/2020/04/ftc-sends-21-letters-warning-marketers-stop-making-unsupported

371. US Federal Trade Commission April 24, 2020. Warning Letter. https://www.ftc.gov/system/ files/warning-letters/covid-19-letter_to_swro_ forever_ozone.pdf

372. US Federal Trade Commission October 1, 2020: Warning Letter. https://www.ftc.gov/system/ files/warning-letters/covid-19-letter_to_the_ fuel_stop.pdf 
373. US Federal Trade Commission March 18, 2021. Warning Letter. https://www.ftc.gov/system/ files/warning-letters/covid-19-letter-butterfly-holistic-center.pdf

374. US Federal Trade Commission March 18, 2021. Warning Letter. https://www.ftc.gov/system/ files/warning-letters/covid-19-letter-butterfly-holistic-center.pdf

375. Federal Trade Commission, April 29, 2021: Advertisers: Stop unproven COVID claims or face penalties under new law. https://www.ftc.gov/ news-events/blogs/business-blog/2021/04/advertisers-stop-unproven-covid-claims-or-face-penalties
376. US Federal Trade Commission April 29, 2021. The FTC Directed 30 More Marketers to Stop Making Unsupported Claims That Their Products and Therapies Can Effectively Prevent or Treat COID-19. https://www.ftc.gov/news-events/press-releases/2021/04/ftc-directed-30-more-marketers-stop-making-unsupported-claims

377. Makary MA, Daniel M. Medical error-the third leading cause of death in the US. BMJ. 2016 May 3. 353;i2139.

378. Lazarou J, Pomeranz BH, Corey PN. Incidence of adverse drug reactions in hospitalized patients: a meta-analysis of prospective studies. JAMA. 1998 Apr 15. 279(15);1200-5. 